\title{
Inorganic and Polymeric Nanoparticles for Human Viral and Bacterial Infections Prevention and Treatment
}

\author{
John Jairo Aguilera-Correa ${ }^{1, *(\mathbb{D})}$, Jaime Esteban ${ }^{2}$ (D) and María Vallet-Regí 1,3,*(D) \\ 1 Department of Chemistry in Pharmaceutical Sciences, School of Pharmacy, Research Institute Hospital 12 de \\ Octubre (i+12), Complutense University of Madrid, Plaza Ramón y Cajal s/n, 28040 Madrid, Spain \\ 2 Clinical Microbiology Department, Jiménez Díaz Foundation Health Research Institute, \\ Autonomous University of Madrid, Av. Reyes Católicos 2, 28040 Madrid, Spain; jestebanmoreno@gmail.com \\ 3 Networking Research Center on Bioengineering, Biomaterials and Nanomedicine (CIBER-BBN), \\ 28029 Madrid, Spain \\ * Correspondence: john_j2a@hotmail.com (J.J.A.-C.); vallet@ucm.es (M.V.-R.); Tel.: +34-91-394-1843 (M.V.-R.)
}

Citation: Aguilera-Correa, J.J.;

Esteban, J.; Vallet-Regí, M. Inorganic and Polymeric Nanoparticles for Human Viral and Bacterial Infections Prevention and Treatment. Nanomaterials 2021, 11, 137. https:// doi.org/10.3390/nano11010137

Received: 22 December 2020

Accepted: 5 January 2021

Published: 8 January 2021

Publisher's Note: MDPI stays neutral with regard to jurisdictional clai$\mathrm{ms}$ in published maps and institutional affiliations.

Copyright: (C) 2021 by the authors. Licensee MDPI, Basel, Switzerland. This article is an open access article distributed under the terms and conditions of the Creative Commons Attribution (CC BY) license (https:// creativecommons.org/licenses/by/ $4.0 /)$.

\begin{abstract}
Infectious diseases hold third place in the top 10 causes of death worldwide and were responsible for more than 6.7 million deaths in 2016. Nanomedicine is a multidisciplinary field which is based on the application of nanotechnology for medical purposes and can be defined as the use of nanomaterials for diagnosis, monitoring, control, prevention, and treatment of diseases, including infectious diseases. One of the most used nanomaterials in nanomedicine are nanoparticles, particles with a nano-scale size that show highly tunable physical and optical properties, and the capacity to a wide library of compounds. This manuscript is intended to be a comprehensive review of the available recent literature on nanoparticles used for the prevention and treatment of human infectious diseases caused by different viruses, and bacteria from a clinical point of view by basing on original articles which talk about what has been made to date and excluding commercial products, but also by highlighting what has not been still made and some clinical concepts that must be considered for futures nanoparticles-based technologies applications.
\end{abstract}

Keywords: nanomedicine; nanoparticles; viral infection; bacterial infection

\section{Introduction}

Infectious diseases still represent a huge constant threat for humanity [1]. In fact, they hold third place in the top 10 causes of death worldwide and were guilty of more than 6.7 million deaths in 2016 [2]. Among them, 3 million deaths have been caused by lower respiratory infections, 1.4 million deaths have been caused by diarrheal diseases, 1.3 million deaths have been caused by tuberculosis, and one million deaths have been caused by human immunodeficiency virus (HIV) and its complications [2]. These diseases are linked together to both important economic risk for the health system and social ones, and the implications of these associations ranging from individual ordinary people to geopolitical stability [1].

Although this global mortality has recently dropped worldwide thanks to the discovery of antimicrobials and the use of adequate treatments, death rates continue to differ depending on the economy of each country [3]. Despite the existence of many adequate antimicrobial treatments, these will always be connected to the problem of antimicrobial resistance. The introduction in the clinical practice of a new antibiotic is followed by the detection of resistant microorganisms after some variable period in almost all cases. This antimicrobial resistance is due to three major factors: (1) the increasing frequency of antimicrobial-resistant phenotypes among microbes as a result of the selective pressure which the widespread use of antimicrobials exert on the microbes; (2) the globalization, which allows the rapid spread of pathogens from a specific localization to the whole world; and (3) the inappropriate use of antimicrobials in many different settings [4]. The importance of antimicrobial resistance seems to be increasing, and a multidisciplinary, 
collaborative, regulatory approach is imperiously required for combating this problem, this approach should mainly include rational use of antimicrobials, regulation on overthe-counter availability of antibiotics, improving hand hygiene and improving infection prevention and control, but also the understanding of resistance mechanism and innovation in new drugs and vaccines [5]. One of these innovative approaches is nanomedicine.

Nanomedicine is a multidisciplinary field that is based on the application of nanotechnology for medical purposes and can be defined as the use of nanomaterials for diagnosis, monitoring, control, prevention, and treatment of diseases [6-12] (Figure 1). Nanomedicine intends to change the clinical practice and introduce novel medicines for both diagnosis and treatment, which can: (1) integrate effective molecules that otherwise could not be used due to their intrinsic high toxicity, (2) exploit multiple mechanisms of action, (3) maximize efficacy whilst dose and toxicity are reduced, and (4) provide drug targeting, controlled and site-specific release $[7,11,13]$. One of the most used nanomaterials in nanomedicine are nanoparticles, nano-scale particles that show highly tunable physical and optical properties and the capacity to form a wide library of compounds [13]. This manuscript is intended to be a comprehensive review of the available recent literature on nanoparticles used for the prevention and treatment of human infectious diseases caused by different microorganisms from a medical point of view by basing on original articles which talk about what has been made to date and excluding commercial products, but also by highlighting what has not been still made and some clinical concepts that must be considered for futures nanoparticles-based technologies applications.

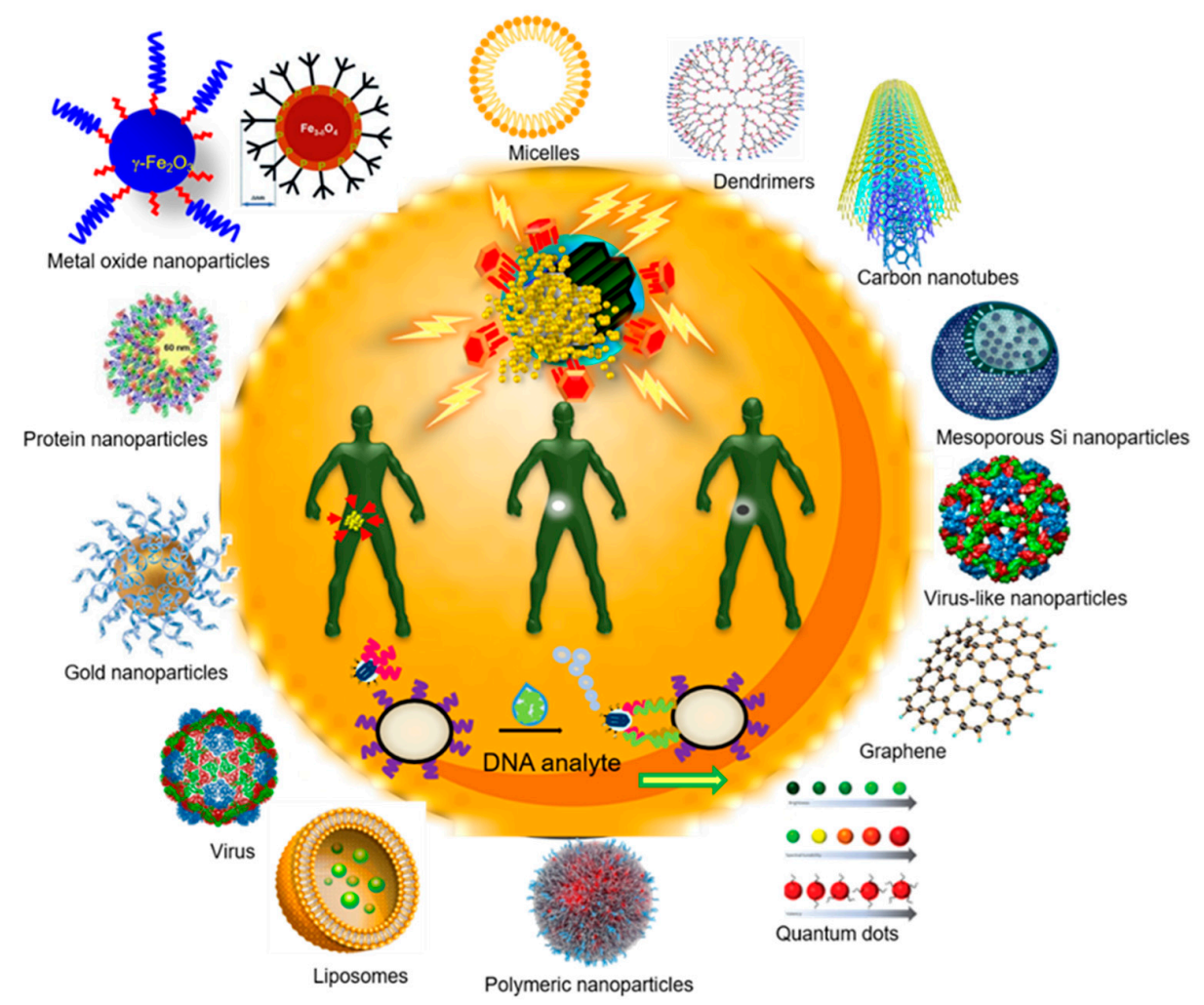

Figure 1. Different types of nanoparticles, both inorganic and polymeric ones, are represented on the outside. Inside, the different functions that can be achieved with the use of nanomedicine are represented: drug release and targeted therapy (improving the pharmacological profile, specific release to target tissues, overcoming biological barriers, and reducing side effects), diagnosis (increased sensitivity, speed and accuracy, early diagnosis, and specific detection of pathological biomarkers), theranosis (focused detection and therapy of diseases, visualizing and evaluating the effectiveness of treatment), and nanodevices (biosensors with greater accuracy and sensitivity, and nanorobots for detection and repair at the cellular level). 


\section{Nanoparticles Types and Their Uses}

A nanoparticle (NP) is a nanoscopic object with three external nanoscale dimensions [8] generally ranging from nanometers or minus to micrometers [14] which may show antimicrobial properties per se or even act as an antimicrobial carrier. One of the main attractions of NPs is the possibility of functionalization. Functionalization allows altering the chemical and physical properties of an NP with a specific purpose or multiple ones (multifunctionalization). This process can give rise to local or directed antimicrobial delivery, prolong antimicrobial effects, facilitate transport into target microbial cells, and/or locate an area of infection, among others $[10,15,16]$. This functionalization can be carried out by incorporating different components such as surface ligands that mediate the specific attachment of NPs, linker molecules that release the cargo carried by the NP at the desired site in response to a concrete environmental trigger, one or more therapeutic cargoes that are transported by the NP, and/or a coating, which is generally designed for improving the biocompatibility and bioavailability of the NPs in the inside of human body $[16,17]$.

Considering the temporal order, NPs related to an infection can be divided into NPs from the old toolbox (e.g., liposomes, viruses, and dendrimers), and the young toolbox (e.g., mesoporous silica NPs, carbon nanotubes, fulerenes, graphene). However, the main classification used classifies them into two categories: (1) inorganic and (2) polymeric NPs.

\subsection{Inorganic Nanoparticles}

These NPs include metal and metal oxide NPs which can be synthesized from metals such as gold $(\mathrm{Au})$, silver $(\mathrm{Ag})$, copper $(\mathrm{Cu})$, and / or aluminum $(\mathrm{Al}) \mathrm{NPs}$, metal oxides such as iron oxide, magnesium oxide $(\mathrm{MgO})$, titanium oxide $\left(\mathrm{TiO}_{2}\right)$ and zinc oxide $(\mathrm{ZnO}) \mathrm{NPs}$, and semiconductors such as silicon and ceramics [18]. Inorganic NPs can withstand harsh process conditions and have been considered safe materials for humans and animals [19]. The antimicrobial effect of these NPs depends on certain characteristics such as size, shape, $\zeta$-potential, ligands, $\mathrm{pH}$, roughness, stability, crystal structure, and material used, but the relationship between these characteristics and their antimicrobial ability is not wellunderstood to date $[20,21]$. Their antimicrobial abilities may generally result from at least four mechanisms: reactive oxygen species (ROS) generation, metallic cations release, nanoparticles accumulation on the immediate environment of microbes, and nanoparticle internalization [22]. Furthermore, microbicidal properties from inorganic NPs do not use to select resistance $[20,21]$. Among inorganic NPs, worthy of note is the mesoporous silica NPs (MSNPs). These nanoparticles are characterized by high chemical stability, high mechanical and heat resistance, and high specific surface area of $1000 \mathrm{~m}^{2} / \mathrm{g}$. They can be chemically synthesized with particle sizes between 75 and $150 \mathrm{~nm}$, with pore diameters between 2 and $12 \mathrm{~nm}$. Each nanoparticle has about 1400 pores, which provides excellent charge storage inside the nanoparticle to store various molecules, particularly drugs. And they have silanol groups that are key to functionalize both its surface and its interior to suit the specific function being pursued [23]. All these features together back up MSNPs as a more than promising nanocarrier for locally antimicrobial delivery for the treatment of different infections $[9,10,17,24-26]$.

\subsection{Polymeric Nanoparticles}

These NPs are made mostly from organic matter. Organic NPs are less stable than inorganic ones, especially at high temperatures and/or pressures [19], but otherwise show excellent biocompatibility, stability, targeting efficiency, and low-hydro-soluble drug storage [27,28]. They represent more than two-thirds of the nano-systems [20,29]. Examples of organic NPs are liposomes, polymeric NPs, micelles, dendrimers, and solid lipid NPs. Liposomes are spherical nanocarriers with a size between 20 and up to $1000 \mathrm{~nm}$ [30] which are made from phospholipid bilayer with an aqueous core [28]. Polymeric NPs are colloids solids with a size from 10 to $1000 \mathrm{~nm}$ and can be made from polycaprolactone, polyacrylate, but also natural polymers such as alginate, and chitosan or even proteins like albumin [31]. Micelles are also spherical nanocarriers composed of a surfactant monolayer, their size is 
ranged between 10 and $1000 \mathrm{~nm}$ [31]. Dendrimers are symmetrical macromolecules with a sized ranging from 10 to $100 \mathrm{~nm}$ composed of three parts (a core, a hyper-branched zone, and terminal functional groups) which allows them to charge multiple chemical molecules and to display multiple surface groups [32]. Lipid solid NPs are formulated from lipids which are solid in the physiological temperature and stabilized by emulsifiers and show a size that varies between 10 to $1000 \mathrm{~nm}$ [33]. Some advantages of organic NPs such as drug protection against harsh environmental situations, ease of large scale production using high-pressure homogenization technique, biocompatibility, and biodegradability set them up as a better alternative lipid-based system [33]. Nanoemulsions are colloidal dispersions composed by small oil droplets suspended in an aqueous phase whose size varies between 20 to $200 \mathrm{~nm}$ [34].

\section{Nanoparticles and Human Infections}

\subsection{Nanoparticles and Human Viral Infections}

Viruses are the most frequent pathogens of epidemic potential. They can give rise to outbreaks in human populations sometimes related to different animal reservoirs [1]. Eleven of the 14 prominent outbreaks humanity have suffered worldwide along 120 years have been viruses, a crucial motive what justifies the importance these pathogens have aroused in nanoparticles field. Moreover, many viruses cause common diseases that can be found worldwide, such as common colds, that can be the cause of enormous economic losses, apart from important morbidity and even mortality [35].

Respiratory viruses are the main cause of mortality worldwide by causing up to 2.7 million deaths in 2015 alone [36]. Among of viruses causing lower respiratory tract infections, the main viruses involved in these diseases are influenza A virus, influenza B virus, metapneumovirus, parainfluenza virus (1-4), rhinovirus, coronavirus (HKU1, NL63, OC43, E229, MERS, SARS-CoV and SARS-CoV-2), enterovirus, and syncytial respiratory virus [37]. Only a few of these viruses, such as influenza A virus, respiratory syncytial virus, and MERS, have been approached by an NPs-based therapy as can be seen in Table 1 . Among the most recently published works, the NPs employed against viral infections are mainly used as antimicrobial per se, and then as antimicrobial plus nanocarrier and they are often inorganic and functionalized. The antiviral mechanisms can be grouped into four types, viral deformation/ inactivation, block the viral entry, virus replication inhibition, and cellular apoptosis inhibition. Unfortunately, most of these mechanisms are focused on viral infection prevention, and the works that approach viral treatment are scarce. This point hinders hugely the NPs clinical use against respiratory viral infection because the treatment would be the most useful. Moreover, most of these works are limited to in vitro studies that do not use to evaluate the cytotoxicity on pneumocytes, and the intranasal or inhaled application by using in vivo model should be explored [38]. In vivo models still keep on being an important outstanding issue for this kind of infection. These models must be performed not only for detecting the infecting virus, but also for evaluating the interaction between NPs and the different tissues and organs involving in the respiratory tract (pharynx, larynx, trachea, and lungs) and the possible local inflammation resulting from it. 
Table 1. Nanoparticles for therapeutical approaches against respiratory viral infections.

\begin{tabular}{|c|c|c|c|c|c|c|c|c|}
\hline Virus & $\begin{array}{c}\text { Nanoparticles (NPs) w/o } \\
\text { Conjugate }\end{array}$ & Size $(n m)$ & $\begin{array}{c}\text { Nanoparticle } \\
\text { Role }\end{array}$ & Action Mechanism & $\begin{array}{c}\text { Cytotoxicity } \\
\text { (\%) }\end{array}$ & $\begin{array}{l}\text { Level } \\
\text { Study }\end{array}$ & $\begin{array}{c}\text { Cell } \\
\text { Lines/Animal } \\
\text { Used In Vivo }\end{array}$ & Reference \\
\hline \multirow[t]{8}{*}{$\begin{array}{l}\text { Influenza A virus } \\
\text { (subtype H1N1) }\end{array}$} & $\begin{array}{l}\text { Ag NPs conjugated with } \\
\text { oseltamivir }\end{array}$ & 3 & $\begin{array}{c}\text { Antimicrobial and } \\
\text { nanocarrier }\end{array}$ & $\begin{array}{l}\text { Viral deformation/viral } \\
\text { entry blocking/apoptosis } \\
\text { inhibition }\end{array}$ & $<10$ & in vitro & MDCK & [39] \\
\hline & $\begin{array}{c}\text { Ag NPs conjugated with } \\
\text { zanamivir }\end{array}$ & 3 & $\begin{array}{c}\text { Antimicrobial and } \\
\text { nanocarrier }\end{array}$ & $\begin{array}{l}\text { Viral deformation/ viral } \\
\text { entry blocking/apoptosis } \\
\text { inhibition }\end{array}$ & $<20$ & in vitro & MDCK & [40] \\
\hline & Au NPs with sialic acid & 14 & Antimicrobial & Viral entry blocking & $<1$ & in vitro & MDCK & [41] \\
\hline & $\begin{array}{l}\text { Liposome loaded with } \\
\text { glycan } \\
\text { sialylneolacto-N-tetraose }\end{array}$ & $1-1000$ & Nanocarrier & Viral entry blocking & - & $\begin{array}{l}\text { in vitro/ } \\
\text { in vivo }\end{array}$ & $\begin{array}{l}\text { MDCK/C57BL/ } \\
6 \text { mice }\end{array}$ & [42] \\
\hline & $\begin{array}{c}\text { Se NPs conjugated with } \\
\text { zanamivir }\end{array}$ & 82 & $\begin{array}{c}\text { Antimicrobial and } \\
\text { nanocarrier }\end{array}$ & $\begin{array}{c}\text { Viral entry } \\
\text { blocking/apoptosis } \\
\text { inhibition }\end{array}$ & $<50$ & in vitro & MDCK & [43] \\
\hline & $\begin{array}{l}\text { Se NPs conjugated with } \\
\text { amantadine }\end{array}$ & 70 & $\begin{array}{c}\text { Antimicrobial and } \\
\text { nanocarrier }\end{array}$ & $\begin{array}{c}\text { Viral entry } \\
\text { blocking/apoptosis } \\
\text { inhibition }\end{array}$ & $<20$ & in vitro & MDCK & [44] \\
\hline & $\begin{array}{l}\text { Se NPs conjugated with } \\
\text { ribavirin }\end{array}$ & 65 & $\begin{array}{c}\text { Antimicrobial and } \\
\text { nanocarrier }\end{array}$ & $\begin{array}{c}\text { Viral entry } \\
\text { blocking/apoptosis } \\
\text { inhibition }\end{array}$ & $<20$ & in vitro & MDCK & [45] \\
\hline & $\begin{array}{l}\text { Se NPs conjugated with } \\
\text { oseltamivir }\end{array}$ & 100 & $\begin{array}{c}\text { Antimicrobial and } \\
\text { nanocarrier }\end{array}$ & $\begin{array}{c}\text { Viral entry } \\
\text { blocking/apoptosis } \\
\text { inhibition }\end{array}$ & $<10$ & in vitro & MDCK & [46] \\
\hline $\begin{array}{l}\text { (H1N1, H3N2, } \\
\text { and H9N1 } \\
\text { subtypes) }\end{array}$ & Porous AuNPs & $154 \pm 37$ & Antimicrobial & Viral entry blocking & $<5$ & in vitro & MDCK & [47] \\
\hline \multirow[t]{3}{*}{$\begin{array}{l}\text { (subtypes H1N1, } \\
\text { H3N2, PR8, B-Bris, } \\
\text { and B-Shan) }\end{array}$} & $\begin{array}{c}\text { Au NPs conjugated with } \\
\text { MES }\end{array}$ & $4 \pm 1$ & Antimicrobial & Infection inhibition & - & in vitro & MDCK & [48] \\
\hline & $\begin{array}{c}\mathrm{TiO}_{2} \text { NPs conjugated } \\
\text { polylysines w/o DNA }\end{array}$ & $>5$ & Antimicrobial & Virus replication inhibition & - & in vitro & MDCK & [49] \\
\hline & $\begin{array}{c}\text { ZnO NPs conjugated with } \\
\text { PEG }\end{array}$ & 18 & Antimicrobial & Viral inactivation & $<20$ & in vitro & MDCK & {$[50]$} \\
\hline
\end{tabular}


Table 1. Cont.

\begin{tabular}{|c|c|c|c|c|c|c|c|c|}
\hline Virus & $\begin{array}{c}\text { Nanoparticles (NPs) w/o } \\
\text { Conjugate }\end{array}$ & Size $(n m)$ & $\begin{array}{c}\text { Nanoparticle } \\
\text { Role }\end{array}$ & Action Mechanism & $\begin{array}{c}\text { Cytotoxicity } \\
\text { (\%) }\end{array}$ & $\begin{array}{l}\text { Level } \\
\text { Study }\end{array}$ & $\begin{array}{c}\text { Cell } \\
\text { Lines/Animal } \\
\text { Used In Vivo }\end{array}$ & Reference \\
\hline (H3N2 subtype) & $\begin{array}{c}\text { Ginkgo biloba leaves } \\
\text { polyphenols } \\
\text { nanoemulsions }\end{array}$ & 389-988 & Nanocarrier & $\begin{array}{l}\text { Virucidal and protective } \\
\text { effect }\end{array}$ & 0 & in vitro & MDCK & [51] \\
\hline \multirow[t]{4}{*}{$\begin{array}{l}\text { Respiratory } \\
\text { syncytial virus }\end{array}$} & Ag NPs & 10 & Antimicrobial & Viral replication inhibition & 0 & $\begin{array}{l}\text { in vitro/ } \\
\text { in vivo }\end{array}$ & $\begin{array}{c}\text { A549, a human } \\
\text { alveolar type } \\
\text { II-like epithelial } \\
\text { cell, and } \\
\text { HEp-2/BALB/c } \\
\text { mice }\end{array}$ & [52] \\
\hline & Ag NPs with curcumin & 20 & Antimicrobial & Viral entry blocking & $<5$ & in vitro & HEp-2 & {$[53]$} \\
\hline & $\begin{array}{c}\text { Au NPs conjugated with } \\
\text { MES/MUS-OT }\end{array}$ & $2.5 \pm 0.7$ & Antimicrobial & $\begin{array}{l}\text { Viral inactivation/viral } \\
\text { deformation }\end{array}$ & 0 & $\begin{array}{l}\text { in vitro/ } \\
\text { in vivo }\end{array}$ & $\begin{array}{c}\text { HeLa, HEK 293T, } \\
\text { CHO-K1, Vero, } \\
\text { Hep-2, and } \\
\text { HT-1080/BALB/c } \\
\text { mice }\end{array}$ & [54] \\
\hline & Porous Si NPs & $5-50$ & Antimicrobial & Viral entry blocking & 0 & in vitro & $\begin{array}{l}\text { CEM SS and } \\
\text { MA-104 }\end{array}$ & [55] \\
\hline MERS & $\begin{array}{l}\text { Au nanorod conjugated } \\
\text { with PH-petide+PEG }\end{array}$ & $54 \pm 18$ & Antimicrobial & Viral entry blocking & 0 & $\begin{array}{l}\text { in vitro/ } \\
\text { in vivo }\end{array}$ & $\begin{array}{l}\text { Huh-7, 293T, and } \\
\text { L02/ICR mice }\end{array}$ & {$[56]$} \\
\hline
\end{tabular}

Abbreviations: PLA: poly(lactic) acid, RSV: respiratory syncytial virus, MES: 3-mercaptoethylsulfonate, MUS: undecanesulfonic acid, OT: 1-octanethiol, MCDK: Madin-Darby Canine Kidney cells, HeLa: human cervical carcinoma cell line ATCC CCL-2, HEK 293T: human embryonic kidney ATCC CRL-3216, CHO-K1: Chinese hamster ovary cell line ATCC CCL-61, Vero: African green monkey fibroblastoid kidney cells ATCC CCL81, Hep-2: human larynx carcinoma epithelial cell line ATCC CCL-23, and HT-1080: human fibrosarcoma cell line ATCC CCL-121, MERS: Middle East respiratory syndrome. 
The contributions which can be added by nanomedicine related to SARS-CoV-2 are noteworthy. This virus is emerging as a huge threat to healthcare and the economy in the whole world [57] and has caused 77,667,963 million cases and at least 1,709,295 [58] million deaths up to date. The main nanotechnological approach can be grouped into three categories: diagnosis technologies, vaccines, and possible therapies [59]. Interestingly, one of these approaches is based on the synthesis of ACE2 coated/embedded nanoflowers or quantum dots for using them to produce chewing gums, nose filters, masks and clothes, and gloves which can inactivate SARS-2 and to limit the viral spread [60].

Viruses are also the most common cause of infectious diarrhea in Western countries [61]. Mortality rate that is inversely proportional to the degree of development of each country [61]. The most common viruses causing diarrhoea are rotavirus, norovirus, and adenovirus. There are few nanoparticles-based prevention or treatment approaches against this type of infection. One of them is $\mathrm{Au} / \mathrm{CuS}$ core/shell NPs which can inactivate norovirus GI.1 (Norwalk) [62]. Only two vaccine-based approaches have been evaluated: (1) a recombinant rotavirus VP6-ferritin NPs against rotavirus infection [63], and (2) norovirus-rotavirus recombinant polyethylene glycol NPs against these viruses [64]. A recent study asserts that gold spheres of $2-20 \mathrm{~nm}$ put onto $\mathrm{SiO}_{2}$ spheres or aggregates of $50-200 \mathrm{~nm}$ can inhibit adenovirus reproduction by $90-100 \%$ in the range of dilutions from $2.5 \times 10^{-2} \mathrm{mg} / \mathrm{mL}$ to $2.5 \times 10^{-6} \mathrm{mg} / \mathrm{mL}$ and did not show cytotoxicity in vitro [65]. The potential NPs-based treatment of these diseases is an attractive clinical opportunity that still rises two important issues, (1) the NP-intestine interaction using in vivo model, and (2) the impact of NP on the natural ecosystems and the measures required for minimizing it $[66,67]$ due to this treatment must be ideally orally-administered and, hence, faecally-eliminated.

More than one million sexually transmitted infections (STIs) are diagnosed every day worldwide [68]. Approximately half of these STIs are caused by four viruses which are currently incurable: HIV, herpes simplex virus (HSV), human papillomavirus (HPV), and hepatitis B virus (HBV). New virus as hepatitis $C$ virus have been added to this list due to the new high-risk sexual practices [69]. Some of these NPs-based therapies are summarized in Table 2 and some of them are illustrated in Figure 2. Their currently incurable character up to date of these viruses made more than necessary the exploration of new treatments against them. Not all of these viruses have attracted the same attention from NPs-based therapies, since HIV has taken up most of it. Approximately 38 million (36.2 million were adults, and 1.8 million were children under 15 years of age) people worldwide were infected by HIV in 2019, and it is foreseen that 1.5 million adults and 150,000 children contract the disease each year [70]. Current HIV treatment is based on the use of antivirals that target the various stages in the life cycle of the virus [31]. The current antiretrovirals are nucleoside/nucleotide reverse transcriptase inhibitors, non-nucleoside inhibitors protease inhibitors, entry/fusion inhibitors, CCR5 antagonists, and integrase inhibitors [71]. Despite this treatment cannot cure HIV, do help HIV patients to live longer, healthier lives at the same time which reduces the risk of HIV transmission [72]. Antiretroviral drug resistance threatens to become the main responsible of HIV treatment failure [73]. Therefore, NP-based studies have proposed different alternatives against this virus (Table 2). The main anti-HIV mechanisms based on NP used are viral inactivation, viral entry blocking, cyto-protection, inactivation, infection inhibition, and latency-breaking. From all these mechanisms those that are nearest from the clinical use would be those related to HIV prevention because the NP incorporation to products like lubricants could be locally and topically prevent HIV transmission. However, in vivo model and clinical trials would be necessary for supporting this use. The use of NP as HIV treatment would still remain so far from the clinical application due to the use of CD4+-T cells specific NPs for attacking the virus in its host cells could cause the same damage than the virus in its worst moment, and the use of a non-CD4+-T cells specific NP could represent an inefficient treatment for this infection. 
Table 2. Nanoparticles for therapeutical approaches against viral STIs.

\begin{tabular}{|c|c|c|c|c|c|c|c|c|}
\hline Virus & Nanoparticles (NPs) w/o Conjugate & Size $(\mathrm{nm})$ & $\begin{array}{c}\text { Nanoparticle } \\
\text { Role }\end{array}$ & Action Mechanism & $\begin{array}{c}\text { Cytotoxicity } \\
(\%)\end{array}$ & Level Study & $\begin{array}{l}\text { Cell Lines/Animal } \\
\text { Used In Vivo }\end{array}$ & Reference \\
\hline \multirow[t]{11}{*}{ HIV } & PVP-coated Ag NPs & $1-10$ & Antimicrobial & Cyto-protection & - & in vitro & Hut-CCR5 & [74] \\
\hline & Au NPs conjugated with peptide triazoles & $13-123$ & Antimicrobial & Viral inactivation & - & in vitro & HOS.T4.R, 293T & [75] \\
\hline & Au NPs coated with sulfate-ended ligand & 2 & Antimicrobial & Infection inhibition & 0 & in vitro & MT-2 & [76] \\
\hline & Carboxilan dendrimers & - & Antimicrobial & Infection inhibition & $<20$ & in vitro & $\begin{array}{l}\text { human CD4+, CD25+, } \\
\text { CD127low }\end{array}$ & [77] \\
\hline & $\begin{array}{l}\text { Carboxilan dendrimers conjugated with } \\
\text { RNA decoy }\end{array}$ & - & Nanocarrier & Cyto-protetion & $<20$ & in vitro & MT4 & [78] \\
\hline & $\begin{array}{l}\qquad \mathrm{Fe}_{3} \mathrm{O}_{4} \mathrm{NPs} \text { loaded with } \\
\text { tenofovir+dextran sulphate] + vorinostat }\end{array}$ & $10 \pm 3$ & Nanocarrier & Latency-breaking & 0 & in vitro & $\begin{array}{l}\text { MTT, primary human } \\
\text { astrocytes }\end{array}$ & [79] \\
\hline & PEG-MA NPs loaded with SMAPP1 & - & Nanocarrier & Latency-breaking & - & in vitro & CCRP-CEM & [80] \\
\hline & $\begin{array}{l}\text { PLGA NPs loaded with efavirenz or } \\
\text { saquinavir }\end{array}$ & 340 & Nanocarrier & $\begin{array}{l}\text { Infection inhibition/infection } \\
\text { treatment }\end{array}$ & 0 & in vitro/ex vivo & $\begin{array}{l}\text { TZM-bL, PM-1 and } \\
\text { CEMx174/macaque } \\
\text { cervicovaginal tissue }\end{array}$ & [81] \\
\hline & $\begin{array}{l}\text { PLGA NPs loaded with maraviroc, } \\
\text { etravirine, and/or raltegravir }\end{array}$ & 200 & Nanocarrier & $\begin{array}{c}\text { Infection inhibition/infection } \\
\text { treatment }\end{array}$ & $<20$ & in vitro/ex vivo & $\begin{array}{l}\text { TZM-bl/human } \\
\text { ectocervical explants }\end{array}$ & [82] \\
\hline & Porous Si NPs & 5-50 & Antimicrobial & Viral entry blocking & 0 & in vitro & CEM SS & [55] \\
\hline & $\begin{array}{l}\mathrm{SiO}_{2} \mathrm{NPs}_{\text {conjugated with GPTMS, }} \\
\text { APTES, and TMPES }\end{array}$ & 354 & Nanocarrier & Infection inhibition & 0 & in vitro & HEK 293T & [83] \\
\hline \multirow[t]{4}{*}{ HSV-1 } & $\begin{array}{l}\mathrm{Fe} 3 \mathrm{O} 4 \mathrm{SiO}_{2} \text { NPs conjugated with } \\
\text { biguanide, polymeric aziridine }\end{array}$ & $150-250$ & $\begin{array}{l}\text { Antimicrobial } \\
\text { and nanocarrier }\end{array}$ & Viral inactivation & $<20$ & in vitro & Vero & \\
\hline & MES-coated Ag NPs & 4 & Antimicrobial & Infection inhibition & 0 & in vitro & Vero & [84] \\
\hline & PLA NPs loaded with cloroquine & $<300$ & Nanocarrier & Viral entry blocking & $<30$ & in vitro & Vero & [85] \\
\hline & PLGA nanosphere loaded with acyclovir & 190-700 & Nanocarrier & Treatment tolerance & - & in vivo & Rabbit & [86] \\
\hline \multirow[t]{2}{*}{ HSV-2 } & Liposomes with siRNA & - & Nanocarrier & Infection inhibition & 0 & in vitro/in vivo & $\begin{array}{l}\text { NIH3T3, Vero/BALBc } \\
\text { mice }\end{array}$ & [87] \\
\hline & PVC NPs loaded with acyclovir & $400 \pm 6$ & Nanocarrier & Infection treatment & - & in vivo & Wistar rats & {$[88,89]$} \\
\hline HSV-1/2 & Mycosinthetized Ag NPs & $4-46$ & Antimicrobial & Infection inhibition & - & in vitro & Vero & [90] \\
\hline \multirow[t]{3}{*}{ HBV } & Ag NPs & $10-50$ & Antimicrobial & $\begin{array}{l}\text { Viral inactivation/Infection } \\
\text { inhibition }\end{array}$ & $<50$ & in vitro & HepAD38 & [1] \\
\hline & $\begin{array}{l}\text { (mPEG)-PLA/PEI, mPEG-PLA-chitosan } \\
\text { NPs loaded with siRNA }\end{array}$ & 500-800 & $\begin{array}{l}\text { Antimicrobial } \\
\text { and nanocarrier }\end{array}$ & $\begin{array}{l}\text { Inhibition of the HBV surface } \\
\text { antigen }\end{array}$ & $<6$ & in vitro & $\mathrm{PLC} / \mathrm{PRF} / 5 \mathrm{c}$ & [91] \\
\hline & $\begin{array}{l}\text { Ginkgo biloba leaves polyphenols } \\
\text { nanoemulsions }\end{array}$ & 389-988 & Nanocarrier & $\begin{array}{l}\text { Inhibition of the HBV surface } \\
\text { antigen }\end{array}$ & 0 & in vitro & HepG 2215 & [51] \\
\hline
\end{tabular}


Table 2. Cont.

\begin{tabular}{|c|c|c|c|c|c|c|c|c|}
\hline Virus & Nanoparticles (NPs) w/o Conjugate & Size (nm) & $\begin{array}{c}\text { Nanoparticle } \\
\text { Role }\end{array}$ & Action Mechanism & $\begin{array}{c}\text { Cytotoxicity } \\
(\%)\end{array}$ & Level Study & $\begin{array}{l}\text { Cell Lines/Animal } \\
\text { Used In Vivo }\end{array}$ & Reference \\
\hline \multirow[t]{9}{*}{$\mathrm{HCV}$} & $\begin{array}{l}\text { PEG-PLDn+PEG-PLEm NPs loaded with } \\
\text { antiviral peptides }\end{array}$ & $20-40$ & Nanocarrier & Cyto-protection & 0 & in vitro & Huh-7.5 & [92] \\
\hline & $\begin{array}{l}\text { Anionic poly(amino acid)-based NPs } \\
\text { loaded with antiviral peptides }\end{array}$ & 108 & Nanocarrier & Infection treatment & 0 & in vitro/ in vivo & Huh-7.5/BALBc mice & [93] \\
\hline & Chitosan-TTP NPs loaded with siRNA & $<500$ & Nanocarrier & Infection treatment & $<10$ & in vitro & CHO K1 & [94] \\
\hline & Solid lipid NPs loaded with RNAi & 240 & Nanocarrier & Infection treatment & 10 & in vitro & HepG2 & [95] \\
\hline & $\mathrm{Cu}$ NPs & $45.4 \pm 6.8$ & Antimicrobial & Viral entry blocking & $<5$ & in vitro & Huh-7.5 & [96] \\
\hline & $\begin{array}{l}\text { Dextran-coated magnetic Fe oxide NP } \\
\text { conjugated with DNAzyme }\end{array}$ & $75-80$ & Nanocarrier & $\begin{array}{l}\text { Inhibition of expression of the } \\
\text { HCV NS3 gene }\end{array}$ & - & in vitro/in vivo & $\begin{array}{c}\text { Huh-7 } \\
\text { Luc-Neo/BALBc mice }\end{array}$ & [97] \\
\hline & Silibinin-encapsulated liposome & $129 \pm 3$ & Nanocarrier & $\begin{array}{c}\text { Viral entry blocking/viral } \\
\text { inactivation }\end{array}$ & $<20$ & in vitro & $\begin{array}{c}\text { Huh7.5, } \\
\text { Huh7.5/Conl/FL-Neo }\end{array}$ & [98] \\
\hline & Aptamer-functionalized $\mathrm{Fe}_{2} \mathrm{O}_{3} \mathrm{NPs}$ & 100 & Antimicrobial & Viral inactivation & - & ex vivo & Human plasma & [99] \\
\hline & $\begin{array}{l}\text { Polyanionic carbosilane dendrimers } \mathrm{w} / \mathrm{o} \\
\text { sofosbuvir }\end{array}$ & - & Nanocarrier & Viral entry blocking & 0 & in vitro & $\begin{array}{l}\text { Huh-7, Huh-7.5.1, } \\
\text { Huh-7.5.1-c2 }\end{array}$ & {$[100]$} \\
\hline
\end{tabular}

Abbreviation: PVP: polyvinylpyrrolidine, PLA: polylactide acid, PLG: poly(lactide-co-glycolide, PEG-MA: poly(ethylene glycol) monomethyl ether monomethacrylate, SMSPP: small Molecular Activator of PP1, PGA: polyglycerol adipate, PEG-PLDn: poly(ethylene glycol)-block-poly ( $\alpha$, $\beta$-aspartic acid, PEG-PLEm: methoxy-poly(ethylene glycol)-block-poly(L-glutamic acid), TTP: tripolyphosphate. 


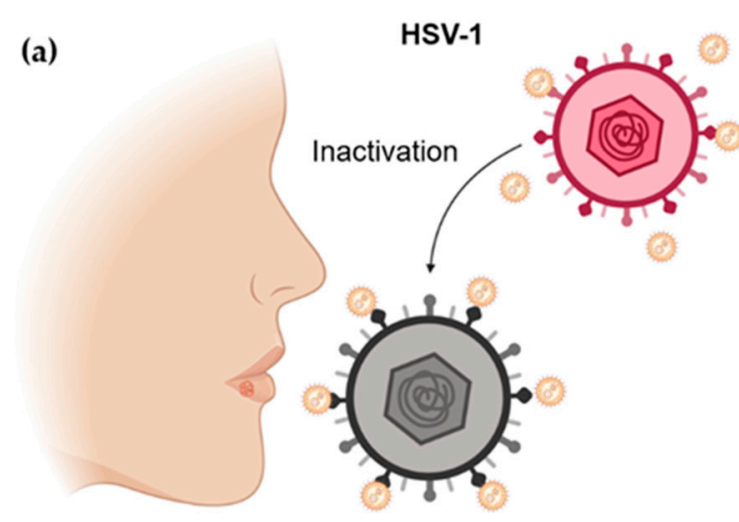

(b)
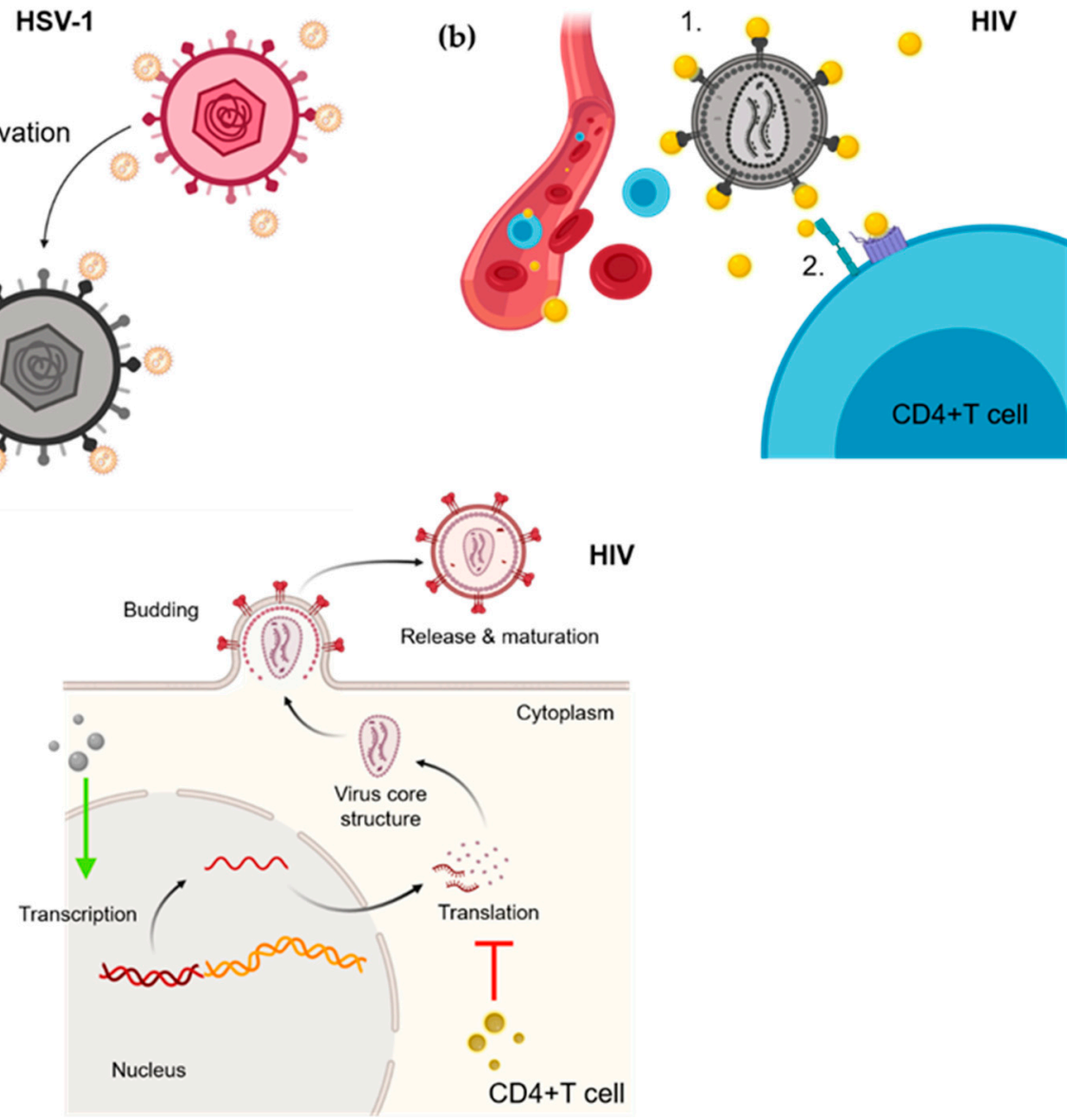

Figure 2. Some of the antiviral mechanisms of NPs. (a) Inactivation of HSV-1 virions. (b) Inactivation of HIV virions (1) and viral entry blocking (2) throughout interaction between NPs and viral cell receptors. (c) Transcription HIV viral DNA favoured by NPs (green arrow) or translation HIV mRNA inhibition (red line).

Herpes genitalis can be a result of HSV-1 or HSV-2 infection. This disease can manifest as a primary or recurrent infection, where the virus replicates in epithelial tissue and establishes dormancy in sensory neurons from where it can reactivate periodically as localized recurrent lesions [101]. Due to the pathogeny of this kind of viruses, the best therapeutical approach should be prevention. Several in vitro studies using NPs have demonstrated the ability to inactivate virions, blocking the viral entry, and the viral infection inhibition (Table 2). However, in vivo model and clinical trials would be necessary for backing up this use. At this point, it is worth making a specification between these viruses since HSV-2 infection prevention can take place previously to sexual contact, but HSV-1 infection prevention is much more difficult because this infection can be transmitted by both genital-genital, oral-genital and oral-oral routes, this would hinder the use of specific NPs-based prevention treatment and the application site (mouth or genitals).

Regarding HPV, the nanoparticle-based approaches are mainly focused on the vaccine against this virus and have been recently reviewed [102].

$\mathrm{HBV}$ is mainly related to an acute hepatitis that rarely gives rise to fulminant hepatitis. HCB instead does not use to cause acute icteric hepatitis buy do cause a chronic infection in the majority of cases [103]. Both of infections are able to cause cirrhosis and liver cancer ensue in $20 \%$ or more over the next $10-50$ years [103]. The main mechanism based on NP against viral hepatitis are viral inactivation, viral entry blocking, cyto-protection, inactivation, and infection inhibition (Table 2). Again, the most promising mechanism are associated with the local and topical prevention by incorporating the NP to lubricants. 
Despite there are multiple functionalizations that can be performed on NPs for becoming them in a perfect medication capturable by the liver (e.g., positively-charged $>200 \mathrm{~nm}$-sized nanoparticles [104]), an inflammation derivate from NP-recruitment by liver could generate a hepatitis similar to the viral acute infection.

\subsection{Nanoparticles and Human Bacterial Infections}

Only three of 14 most important outbreaks humanity has suffered worldwide during the past 120 years have been caused by two bacteria, Vibrio cholerae and Yersinia pestis. Cholera is an acute, secretory diarrhoea provoked by infection with Vibrio cholerae of the $\mathrm{O} 1$ and $\mathrm{O} 139$ serogroups [105]. This disease is endemic in over 50 countries and also causes large epidemics and have been causing severe pandemics since 1812 [105]. Its epidemics have been recently increasing in intensity, duration and frequency, underlying the need for more effective approaches to prevention and control [105]. One of these approaches is the NPs-based therapy. A recent work asserts that ZnO NPs form a complex with cholera toxin, compromises its secondary structure, and blocks its interaction with its receptor in enterocytes and thus reduces cholera toxin uptake [106]. The main inconvenient of this approach would be the possible threat which ZnO NPs would suppose for the environment [107]. Another current work has demonstrated that GM1 ganglioside-coated PLGA hybrid NPs able to recruit cholera toxin and impede its interaction with its receptor in enterocytes by using a murine in vivo model [108]. The biodegradable character of PLGA NPs made them more clinically applicable and harmless to the environment. Plague is caused by Yersinia pestis and is infrequent in clinics, though natural plague foci can be found widely distributed around the world [109]. Its three major clinical forms include bubonic, pneumonic, and septicaemic plague and all of them are usually related to a very high mortality rate [109]. Recently, nanomedicine has provided a new promising vaccine based on bacteriophage T4 capsid-derivate nanoparticles which induce immunity by using the capsular protein Caf1 and the low calcium response protein LcrV from Y. pestis [110]. Another bacterial species related to outbreaks during human history is Mycobacterium tuberculosis [111]. In 2018 only, approximately 10 million incident cases and 1.5 million deaths were attributed to this bacterium [112]. The current increasing existence of multidrug resistant and extensively drug-resistant strains makes the treatment of this disease an important problem in the present and, potentially, future years [113]. Some current NPsbased approaches have been concerned about this infection and have demonstrated that M. tuberculosis show in vitro susceptibility to $\mathrm{Ag}$ [114], selenium (Se) [115], and $\mathrm{TiO}_{2}$ [116] NPs, but their intracellularly anti-tuberculosis activity remains unclear. Up to date, only a work asserts that PLGA NPs loaded with a highly hydrophobic citral-derived isoniazid analogue promote antibiotic targeting into replicating extra- and intracellular M. tuberculosis bacilli [117].

A present problem with bacterial infections is the emerging threat of antibiotic resistance since bacteria are the most common microorganisms associated with many human infections including most of the healthcare-related infections throughout the world [1]. According to a report from the Centers for Disease Control, more than 2.8 million antibioticresistant bacterial infections occur in the United States every year and are associated with more than 35,000 deaths [118]. The priority pathogens related to this antibiotic resistance are (in order of priority) Acinetrobacter baumannii, Pseudomonas aeruginosa, enterobacteria (e.g., Klebsiella pneumoniae and Enterobacter cloacae), Enterococcus faecium, Staphylococcus aureus, Helicobacter pylory, Campylobacter spp, Samonella spp., Neisseria gonorrhoeae, Streptococcus pneumoniae, Haemophilus influenzae, and Shigella spp. [1,119]. Despite this, only a few species from this list have been evaluated in NP-based studies (Table 3). The antibiotic-resistance mechanisms can be summarized in four groups: limiting uptake of an antibiotic, modification of an antibiotic target, inactivation of an antibiotic, and active efflux of an antibiotic [120]. It is indisputable that the antibiotic-resistant bacteria appearance is taking place faster than the new antibiotic discovery and development, a process that requires tremendous economic and labour investment for pharmaceutical industries and is time-consuming [21,121]. More- 
over, some of these antibiotic-resistant bacterial infections demand the use of high and/or longer doses of antibiotics or the use of antibiotics generally relegated to a second or even third treatment line because of their toxicity. Thus, behind this scenario, the application of NPs is showed as a potential strategy against these microorganisms [98]. The main antibacterial mechanisms of NPs that show an antibacterial effect per se can be grouped into four categories: (outer and/or cytoplasmatic) membrane damage, protein blocking/inactivation, protein synthesis blocking, and DNA damage (Figure 3). The antibacterial effect of metal NPs have explored and widely reviewed the in vitro antibacterial ability of different heavy metal NPs [122-128]. Nanoparticles containing Ag [129-135], Au [136-139], $\mathrm{TiO}_{2}$ [140-142], $\mathrm{ZnO}$ [143-145], $\mathrm{CuO}$ [146,147], $\mathrm{MgO}$ [148,149], $\mathrm{CaO}$ [150-152], $\mathrm{Al}_{2} \mathrm{O}_{3}$ [153-155], $\mathrm{SiO}_{2}$ [156], and clay [157] have shown a great potential antibacterial activity. Some modifications using proteins such as zein protein can give certain metal nanoparticles greater antibacterial capacity, for example zein-coated Au NPs against $P$. aeruginosa [158] or the composite consisting of zein protein and Ag NPs against S. aureus [159]. Most of metallic NPs showed positive in vitro antibacterial effects mainly resulting of the bacterial toxic cationic release or ROS generation (Table 3), but these two mechanisms could be diminished by several in vivo considerations. Firstly, the in vivo environment is an polyanionic system [160] where metal cations might be attracted by other host molecules, what might deviate these NPs from its antimicrobial path at systemic level or decrease the cation concentration in the immediate environment of the area of infection. Secondly, ROS generated by NPs could be considerably decreased or neutralized in vivo by biomolecules that can hijack them, e.g., ascorbic acid (vitamin C), uric acid, bilirubin, albumin, glutathione, $\gamma$-tocopherol (vitamin E) or ubiquinol of blood lipoproteins [161,162]. Moreover, metals NPs may give rise to immunotoxicity, cytotoxicity, and genotoxicity in both pathogenic bacteria and health human cells $[163,164]$. Taking into account all these points, the most probable clinical use against bacterial infections of metal NPs would be restricted to topical or local use. Over the last few years, other element such as, nickel [165,166], cerium [166,167], Se [168,169], caesium [170], yttrium [171], palladium [172,173], or superparamagnetic Fe NPs [174] have been recently employed in the battle against antibiotic-resistant bacteria [21,125], but more studies that include cytotoxicity and biocompatibility are necessary. 
Table 3. Nanoparticles designed for therapeutical approaches against bacterial infections.

\begin{tabular}{|c|c|c|c|c|c|c|c|c|c|c|}
\hline $\begin{array}{l}\text { Nanoparticles (NPs) } \\
\text { w/o Conjugate }\end{array}$ & Size $(\mathrm{nm})$ & $\begin{array}{l}\text { Nanoparticle } \\
\text { Role }\end{array}$ & $\begin{array}{c}\text { Action } \\
\text { Mechanism }\end{array}$ & $\begin{array}{c}\text { Bacterial } \\
\text { Species }\end{array}$ & Application & Life Style & $\begin{array}{c}\text { Cytotoxicity } \\
(\%)\end{array}$ & Level Study & $\begin{array}{c}\text { Cell } \\
\text { Lines/Animal } \\
\text { Used In Vivo } \\
\end{array}$ & Reference \\
\hline $\mathrm{Au} / \mathrm{Ag}$ nanorods & $12-14 \times 50-55$ & Antimicrobial & $\mathrm{Ag}+$ release & E. coli, MRSA & $\begin{array}{l}\text { S. aureus-related } \\
\text { and E. coli-related } \\
\text { infections }\end{array}$ & Planktonic & 0 & $\begin{array}{l}\text { In vitro/ } \\
\text { in vivo }\end{array}$ & -/C57BL6 mice & [175] \\
\hline $\begin{array}{l}\text { TBD-PEG NPs loaded } \\
\text { with IR786S, ONOO- } \\
\text { and ClO- }\end{array}$ & 50 & Nanocarrier & ROS generation & E. coli & $\begin{array}{l}\text { Wound infection } \\
\text { and abscessus } \\
\text { cauded by E. coli }\end{array}$ & Biofilm & - & $-/$ In vivo & -/BALBc mice & {$[176]$} \\
\hline $\begin{array}{l}\text { Ag NPs anchored on Ti } \\
\text { surface }\end{array}$ & $18-24$ & Antimicrobial & $\mathrm{Ag}+$ release & S. epidermidis & $\begin{array}{l}\text { Metallic implant } \\
\text { infection }\end{array}$ & $\begin{array}{c}\text { Planktonic/ } \\
\text { biofilm }\end{array}$ & $<10$ & $\begin{array}{l}\text { In vitro/ } \\
\text { in vivo }\end{array}$ & $\begin{array}{c}\text { MC3T3- } \\
\text { E1/Sprague } \\
\text { Dawley rats }\end{array}$ & [177] \\
\hline $\begin{array}{l}\text { ZnO NPs dispersed in } \\
\text { a polyvinyl alcohol gel }\end{array}$ & $4-10$ & Antimicrobial & ROS generation & E. coli & Vaginitis & Planktonic & $<20$ & $\begin{array}{l}\text { In vitro/ } \\
\text { in vivo }\end{array}$ & $\begin{array}{l}\text { HepG-2, A-431/ } \\
\text { ICR mice }\end{array}$ & [178] \\
\hline $\begin{array}{l}\mathrm{Ag} \text { NPs in a poly } \\
\text { (hydroxyethyl } \\
\text { methacrylate) gel }\end{array}$ & - & Antimicrobial & $\mathrm{Ag}+$ release & S. aureus/E. coli & $\begin{array}{l}\text { Idwelling implant } \\
\text { infection }\end{array}$ & Planktonic & $<20$ & $\begin{array}{l}\text { In vitro/ } \\
\text { in vivo }\end{array}$ & $\begin{array}{l}\mathrm{NIH}-3 \mathrm{~T} 3 / \mathrm{BALBC} \\
\text { mice }\end{array}$ & [179] \\
\hline $\begin{array}{l}\text { P(GEMADA-co-DMA)- } \\
\text { b-PBMA NPs loaded } \\
\text { with guanidine lighted } \\
\text { with NIR laser }\end{array}$ & 50 & Nanocarrier & ROS generation & S. aureus & Catheter infection & $\begin{array}{c}\text { Planktonic/ } \\
\text { biofilm }\end{array}$ & - & $\begin{array}{l}\text { In vitro/ } \\
\text { in vivo }\end{array}$ & -/BALBc mice & [180] \\
\hline $\begin{array}{l}\text { Ag NPs loaded into Ti } \\
\text { nanotubes }\end{array}$ & $10-20$ & Antimicrobial & $\mathrm{Ag}+$ release & MRSA & $\begin{array}{l}\text { Metallic implant } \\
\text { infection }\end{array}$ & Biofilm & - & $\begin{array}{l}\text { In vitro/ } \\
\text { in vivo }\end{array}$ & $\begin{array}{c}\text { MC3T3- } \\
\text { E1/Sprague } \\
\text { Dawley rats }\end{array}$ & [181] \\
\hline $\begin{array}{l}\text { Dendrimer-coated } \\
\text { MSNPs load with } \\
\text { levofloxacin }\end{array}$ & 150 & Nanocarrier & $\begin{array}{l}\text { Antibiotic- } \\
\text { bactericidal effect } \\
\text { favored by } \\
\text { dendrimer }\end{array}$ & E. coli & $\begin{array}{l}\text { E. coli } \\
\text { biofilm-related } \\
\text { infection }\end{array}$ & $\begin{array}{c}\text { Planktonic/ } \\
\text { biofilm }\end{array}$ & - & In vitro & - & [182] \\
\hline $\begin{array}{c}\varepsilon \text {-poly-lysine-coated } \\
\text { MSNPs were loaded } \\
\text { with histidine kinase } \\
\text { autophosphorylation } \\
\text { inhibitors (HKAI) }\end{array}$ & 100 & Nanocarrier & $\begin{array}{l}\text { HKAI-inhibitory } \\
\text { effect }\end{array}$ & $\begin{array}{l}\text { E. coli, Serratia } \\
\text { marcensens }\end{array}$ & $\begin{array}{l}\text { Enterobacterial } \\
\text { infection }\end{array}$ & Planktonic & 0 & $\begin{array}{l}\text { In vitro/ } \\
\text { in vivo }\end{array}$ & $\begin{array}{l}\text { Caco-2 BBE, RAW } \\
264.7 / \text { Zebra fish }\end{array}$ & [183] \\
\hline $\begin{array}{l}\text { EDC/NHS or } \\
\text { ICPTES-functionalized } \\
\text { mesoporous } \mathrm{SiO}_{2} \mathrm{NPs}\end{array}$ & - & Nanocarrier & $\begin{array}{c}\text { Antibiotic- } \\
\text { bactericidal effect } \\
\text { of the possible } \\
\text { loaded antibiotic }\end{array}$ & $\begin{array}{l}\text { Francisella } \\
\text { tularensis }\end{array}$ & Turalemia & Planktonic & - & In vitro & - & [184] \\
\hline $\begin{array}{c}\text { Anti-S. aureus } \\
\text { antibody-coated } \\
\text { Fe3O4/MSNPs loaded } \\
\text { with vancomycin }\end{array}$ & 250 & Nanocarrier & $\begin{array}{l}\text { Vacomycin- } \\
\text { bactericidal } \\
\text { effect }\end{array}$ & S. aureus & $\begin{array}{l}\text { S. aureus- } \\
\text { associated } \\
\text { bacteremia }\end{array}$ & Planktonic & - & In vitro & Erytrocyte & [185] \\
\hline
\end{tabular}


Table 3. Cont

\begin{tabular}{|c|c|c|c|c|c|c|c|c|c|c|}
\hline $\begin{array}{l}\text { Nanoparticles (NPs) } \\
\text { w/o Conjugate }\end{array}$ & Size (nm) & $\begin{array}{l}\text { Nanoparticle } \\
\text { Role }\end{array}$ & $\begin{array}{c}\text { Action } \\
\text { Mechanism }\end{array}$ & $\begin{array}{l}\text { Bacterial } \\
\text { Species }\end{array}$ & Application & Life Style & $\begin{array}{l}\text { Cytotoxicity } \\
(\%)\end{array}$ & Level Study & $\begin{array}{c}\text { Cell } \\
\text { Lines/Animal } \\
\text { Used In Vivo } \\
\end{array}$ & Reference \\
\hline $\begin{array}{l}\text { Aptemr-gated MSNPs } \\
\text { loaded with } \\
\text { vancomycin }\end{array}$ & 177.5 & Nanocarrier & $\begin{array}{l}\text { Vacomycin- } \\
\text { bactericidal } \\
\text { effect }\end{array}$ & $\begin{array}{l}\text { S. aureus/S. } \\
\text { epidermidis }\end{array}$ & $\begin{array}{l}\text { Staphylococcal } \\
\text { infections }\end{array}$ & Planktonic & - & - & - & [186] \\
\hline $\begin{array}{l}\text { Lipidids-coated } \\
\text { MSNPs loaded with } \\
\text { gentamicin and } \\
\text { conjugated with } \\
\text { UBI29-41 }\end{array}$ & 81.2-99.5 & Nanocarrier & $\begin{array}{l}\text { Gentamicin- } \\
\text { bacteriostatic } \\
\text { effect }\end{array}$ & S. aureus & $\begin{array}{l}\text { S. aureus- } \\
\text { associated bone } \\
\text { infections }\end{array}$ & $\begin{array}{l}\text { Planktonic/ } \\
\text { Intracellular }\end{array}$ & $<20$ & In vitro & $\begin{array}{l}\text { MC3T3-E1, RAW } \\
264.7\end{array}$ & [187] \\
\hline $\begin{array}{c}\text { Lipidids-coated } \\
\text { MSNPs loaded with } \\
\text { colistin and conjugated } \\
\text { with LL-37 }\end{array}$ & $80-99.6$ & Nanocarrier & $\begin{array}{l}\text { Colisitn- } \\
\text { bactericidal } \\
\text { effect }\end{array}$ & P. aeruginosa & $\begin{array}{l}\text { P. aeruginosa- } \\
\text { associated } \\
\text { pulmonar } \\
\text { infections }\end{array}$ & $\begin{array}{l}\text { Planktonic/ } \\
\text { Intracellular }\end{array}$ & $<20$ & In vitro & A549 & [188] \\
\hline $\begin{array}{l}\text { Trehalose-coated } \\
\text { PFPA-functionalized } \\
\text { MSNPs loaded with } \\
\text { isozianid }\end{array}$ & $154-188$ & Nanocarrier & $\begin{array}{l}\text { Isozianid- } \\
\text { bactericidal } \\
\text { effect }\end{array}$ & M. smegmatis & $\begin{array}{l}\text { Mycobacterial } \\
\text { infections }\end{array}$ & Planktonic & - & - & - & [189] \\
\hline $\begin{array}{l}\text { Arginine-coated } \\
\text { MSNPs loaded with } \\
\text { ciprofloxacin }\end{array}$ & 75 & Nanocarrier & $\begin{array}{l}\text { Ciprofloxacin- } \\
\text { bactericidal } \\
\text { effect }\end{array}$ & $\begin{array}{c}\text { Salmonella } \\
\text { enterica serovar } \\
\text { typhimurium }\end{array}$ & Salmonellosis & Planktonic & Low & $\begin{array}{l}\text { In vitro/ } \\
\text { in vivo }\end{array}$ & $\begin{array}{c}\text { RAW } \\
\text { 264.7/BALBc mice }\end{array}$ & [190] \\
\hline $\begin{array}{l}\text { FA-CP-FA-coated } \\
\text { MSNPs loaded with } \\
\text { ampicilin }\end{array}$ & 80 & Nanocarrier & $\begin{array}{l}\text { Ampicilin- } \\
\text { bactericidal } \\
\text { effect }\end{array}$ & S. aureus/E. coli & $\begin{array}{l}\text { S. aureus-related } \\
\text { and E. coli-related } \\
\text { infections }\end{array}$ & Planktonic & 0 & $\begin{array}{l}\text { In vitro/ } \\
\text { in vivo }\end{array}$ & $\begin{array}{l}\text { HEK 2931T / Kin } \\
\text { Ming mice }\end{array}$ & [191] \\
\hline $\begin{array}{c}\text { Vancomycin- } \\
\text { functionalized } \\
\text { mesoporous } \mathrm{SiO}_{2} \mathrm{NPs}\end{array}$ & $90-127$ & Nanocarrier & $\begin{array}{l}\text { Vacomycin- } \\
\text { bactericidal } \\
\text { effect }\end{array}$ & S. aureus/E. coli & $\begin{array}{l}\text { S. aureus-related } \\
\text { infections }\end{array}$ & Planktonic & - & $\begin{array}{l}\text { In vitro/ } \\
\text { in vivo }\end{array}$ & -/BALBc mice & [192] \\
\hline $\begin{array}{l}\text { Concavalin- } \\
\text { functionalized MSNPs } \\
\text { loaded with } \\
\text { levofloxacin }\end{array}$ & 120 & Nanocarrier & $\begin{array}{l}\text { Levofloxacin- } \\
\text { bactericidal } \\
\text { effect }\end{array}$ & S. aureus & $\begin{array}{l}\text { S. aureus-related } \\
\text { infections }\end{array}$ & $\begin{array}{l}\text { Planktonic/ } \\
\text { biofilm }\end{array}$ & - & In vitro & - & [193] \\
\hline $\begin{array}{l}\text { Amino-functionalized } \\
\text { MSNPs loaded with } \\
\text { levofloxacin }\end{array}$ & 150 & Nanocarrier & $\begin{array}{l}\text { Levofloxacin- } \\
\text { bactericidal } \\
\text { effect }\end{array}$ & E. coli & $\begin{array}{l}\text { E. coli-related } \\
\text { infection }\end{array}$ & $\begin{array}{l}\text { Planktonic/ } \\
\text { biofilm }\end{array}$ & $<10$ & In vitro & МС3Т3-E1 & [194] \\
\hline NB-401 nanoemulsions & 400 & Nanocarrier & $\begin{array}{l}\text { NB-401- } \\
\text { bactericidal } \\
\text { effect }\end{array}$ & $\begin{array}{l}\text { P. aeruginosa, } A \text {. } \\
\text { xylosoxidans, } S \text {. } \\
\text { maltophilia, } \\
\text { Acinetobacter } \\
\text { species, } \\
\text { Pandoraea } \\
\text { species), and } \\
\text { Ralstonia species }\end{array}$ & $\begin{array}{l}\text { Non-fermenting } \\
\text { Gram-negative } \\
\text { bacteria-related } \\
\text { respiratory } \\
\text { infections }\end{array}$ & $\begin{array}{l}\text { Planktonic/ } \\
\text { biofilm }\end{array}$ & - & In vitro & - & [195] \\
\hline
\end{tabular}


Table 3. Cont.

\begin{tabular}{|c|c|c|c|c|c|c|c|c|c|c|}
\hline $\begin{array}{l}\text { Nanoparticles (NPs) } \\
\text { w/o Conjugate }\end{array}$ & Size $(\mathrm{nm})$ & $\begin{array}{c}\text { Nanoparticle } \\
\text { Role }\end{array}$ & $\begin{array}{c}\text { Action } \\
\text { Mechanism }\end{array}$ & $\begin{array}{l}\text { Bacterial } \\
\text { Species }\end{array}$ & Application & Life Style & $\begin{array}{c}\text { Cytotoxicity } \\
(\%)\end{array}$ & Level Study & $\begin{array}{c}\text { Cell } \\
\text { Lines/Animal } \\
\text { Used In Vivo } \\
\end{array}$ & Reference \\
\hline NB-201 nanoemulsions & 350 & Nanocarrier & $\begin{array}{c}\text { NB-201- } \\
\text { bactericidal } \\
\text { effect }\end{array}$ & P. aeruginosa & $\begin{array}{l}\text { P. aeruginosa burn } \\
\text { infections }\end{array}$ & $\begin{array}{c}\text { Planktonic/ } \\
\text { biofilm }\end{array}$ & - & In vivo & $\begin{array}{l}\text { Sprague-Dawley } \\
\text { rats }\end{array}$ & [196] \\
\hline $\begin{array}{c}\mathrm{N} 5 \text { and } \\
\text { cetylpyridinium } \\
\text { chloride } \\
\text { nanoemulsions }\end{array}$ & 153 & Nanocarrier & $\begin{array}{l}\text { Cetylpyridinium- } \\
\text { bactericidal } \\
\text { effect }\end{array}$ & $\begin{array}{l}\text { Acinetobacter } \\
\text { baumannii }\end{array}$ & $\begin{array}{l}\text { Acinetobacter } \\
\text { baumannii } \\
\text { infections }\end{array}$ & $\begin{array}{l}\text { Planktonic/ } \\
\text { biofilm }\end{array}$ & - & In vitro & - & [197] \\
\hline $\begin{array}{l}\text { Thymus daenensis oil } \\
\text { nanoemulsions }\end{array}$ & 131 & Antimicrobial & $\begin{array}{l}\text { Oil-bactericidal } \\
\text { effect }\end{array}$ & $\begin{array}{c}\text { Haemophilus } \\
\text { influenzze, } \\
\text { Pseudomonas } \\
\text { aeruginosa, and } \\
\text { Streptococcus } \\
\text { pneumoniae }\end{array}$ & $\begin{array}{l}\text { Pneumococcal } \\
\text { infections }\end{array}$ & Planctonic & - & $\begin{array}{l}\text { In vitro/ } \\
\text { in vivo }\end{array}$ & - & [198] \\
\hline $\begin{array}{l}\text { Cleome viscosa oil } \\
\text { nanoemulsions }\end{array}$ & 86 & Antimicrobial & $\begin{array}{l}\text { Oil-bactericidal } \\
\text { effect }\end{array}$ & $\begin{array}{c}\text { Methicillin- } \\
\text { resistant } \\
\text { Staphylococcus } \\
\text { aureus, } \\
\text { drug-resistant } \\
\text { Streptococcus } \\
\text { pyogenes, and } \\
\text { extended } \\
\text { spectrum } \\
\text { beta-lactamase- } \\
\text { producing } \\
\text { Escherichia coli, } \\
\text { Klebsiella } \\
\text { pneumoniae, and } \\
\text { Pseudomonas } \\
\text { aeruginosa }\end{array}$ & $\begin{array}{l}\text { Multidrug- } \\
\text { resistance } \\
\text { bacterial } \\
\text { infections }\end{array}$ & Planctonic & - & $\begin{array}{l}\text { In vitro/ } \\
\text { in vivo }\end{array}$ & - & [199] \\
\hline
\end{tabular}

Abbreviations: MRSA: methicillin-resistant S. aureus. EDC/NHS: 1-ethyl-3-(3-dimethylaminopropyl) carbodiimide/N-hydroxysuccinimide, ICPTES: 3-isocyanatopropyl triethoxysilane,

PEPA: perfluorophenylazide, FA: folic acid, CP: calcium phosphate. 


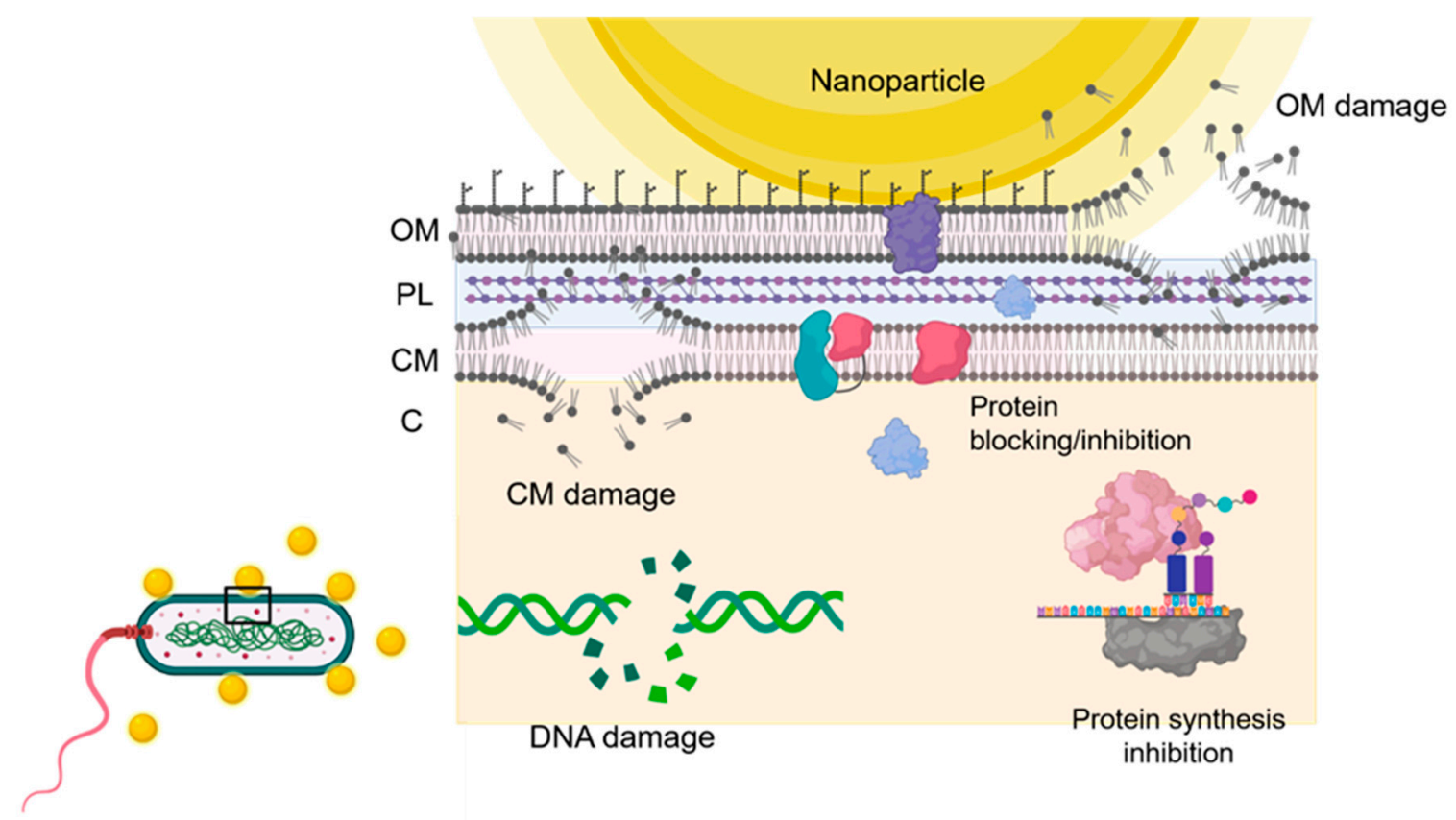

Figure 3. Main antibacterial mechanisms of NPs that show antimicrobial ability per se. OM: outer membrane. PL: peptidoglycan layer. CM: cytoplasmatic membrane. C: cytoplasm.

Liposomes have been considered a useful and valuable tool able to act as drug delivery systems in the treatment of infectious diseases [200]. Nevertheless, a recent and innovative work has demonstrated that liposomes made from cholesterol and/or sphingomyelin were able to sequester the exotoxins of two important pathogenic bacteria, S. aureus and Streptococcus pneumoniae, and protect from their severe invasive infection in a murine in vivo model [201]. In the same vein, the so-called cell-membrane-coated NP, nanoobjects made from a synthetic NP core which can act as nanocarrier surrounded by a layer of natural cell membrane which mimic the complex biochemical properties of the cells from which they come [202], have been used in a bacterial infection model. In this model, rifampicin-loaded and vancomycin-loaded NPs coated with $S$. aureus extravesicular membrane were able to eliminate macrophage-internalized $S$. aureus and to reduce the bacteremia in a murine in vivo model [203].

STIs provoked by bacterial are gaining importance due to their increasing incidence [1]. Among these bacterial pathogens, there are old known diseases like gonorrhea provoked by Neisseria gonorrhoeae, chlamydia caused by Chlamydia trachomatis, chancroid provoked by Haemophilus ducreyi, granuloma inguinale caused by Calymmatobacterium granulomatis, and syphilis provoked by Treponema pallidum, but also there are new ones like campylobacter caused by Campylobacter jejuni and shigellosis provoked by Shigella sonnei and S. flexneri [204]. Only few of all these diseases have been approached by the NP-based therapy. Most studies have been focused on the treatment of N. gonorrhoeae infection. In this sense, Ag NPs plus ceftriaxone [205], mercaptonitrobenzoic acid-coated Ag nanoclusters [206], and chitosan NPs [207] showed a great anti-gonococcal effect with minimal cytotoxicity. It has been also reported that PDGFR- $\beta$ siRNA-PEI-PLGA-PEG NP significantly reduced the intracellular $C$. trachomatis concentration and bacterial extracellular release from infected cells more than $65 \%$ for both of them, while augmenting autophagic degradation and reducing bacterial binding in vitro [208]. Thus, the remaining bacteria STIs set up as a new opportunity for developing new NP-based therapies.

On other hand, there is an important idea that has to be considered: bacteria are able to exist in two non-excluding lifestyles: planktonic or free-life form, or in a sessile form named biofilm. A biofilm is a structured bacterial community enclosed in a 
self-produced polymeric matrix [209] where numerous and complex sociomicrobiological relationships rule [210] (Figure 4a). The adobe-mentioned antibiotic-resistance mechanism can be presented both in planktonic form and in a biofilm of a bacterial strain. However, biofilm form of a bacterium shows different inherent characteristics that give it resistance to almost any unfavourable condition, including the attack of immune system, and antibacterial compounds, such as antibiotics, ROS, and heavy metals [211] (Figure 4b). The biofilm-related infections are estimated about $65 \%$ of all bacterial infections [212]. These bacterial infections include both, device-associated and tissue-associated infections [213], and both types have been addressed by NPs-based therapies (Table 3). Some devicerelated infections are ventricular derivations, contact lenses, endotracheal tubes, central vascular catheters, prosthetic cardiac valves, pacemakers, vascular grafts, tissue fillers, breast implants, peripheral vascular catheters, urinary catheters, orthopaedic implants, and prosthetic joints; and some tissue-related infections are chronic otitis media, chronic sinusitis, chronic tonsilitis, dental plaque, chronic laryngitis, endocarditis, lung infections, kidney stones, biliary tract infections, urinary tract infections, osteomyelitis, and chronic wounds [214], among others. Considering these points, it is pivotal to take into account the NPs susceptibility of biofilm of some bacteria that always trend to form a biofilm, e.g., staphylococci. Still considering the biofilm features, there are NPs-based therapeutical approaches that are a powerful weapon against biofilm-associated infection, for instance, the use of the NPs as an antibacterial or even antibiofilm compounds nanocarrier. It is right here where some porous NPs, e.g., MSNPs, become very important armamentous plethora that can be specifically directed against different types of biofilms according to their functionalization and coatings [24,25,215-217]. Recently, this type of nanosystems is becoming established as a future treatment for biofilm-related infection [182,218], e.g., bone infections $[27,191,195,196]$. Nevertheless, MSNPs applications still arouse questions about their bio-distribution, biocompatibility and the possible inflammatory role they might play during their systemic use [104,219], questions that could be resolved by more and detailed in vivo models.

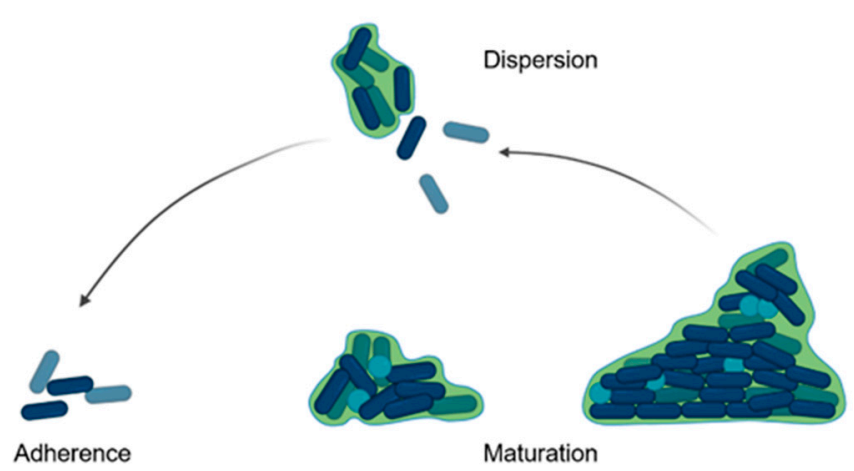

(a)

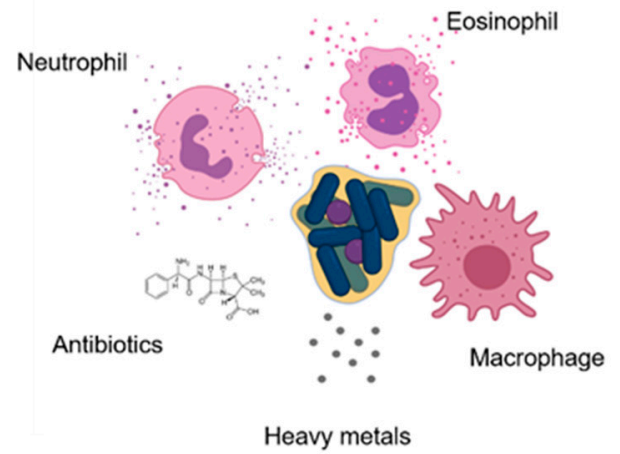

(b)

Figure 4. (a) Bacterial biofilm formation stages. Green represents the biofilm matrix, and light blue cells represent dead bacteria. (b) Inherent characteristics of bacterial biofilm.

\section{Conclusions}

Infections continue to represent a great threat for mankind despite recent medical advances. Nanomedicine based on nanoparticles use provides promising new therapies capable of preventing and treating this kind of infections. Here, we summarize and emphasize multiple approaches that employ nanoparticles as therapeutic agents and antimicrobial cargo system against both viral and bacterial infections from a clinical point of view. According to our review, not all of these therapeutic approaches are equally close to being clinically applied, since infection prevention by using nanoparticles is relatively easier to apply than treatment. In addition, not all administration routes are equally applicable, be- 
cause topical approaches show less obstacles than systemic ones. The way from the bench (in vitro and in vivo studies) to the bed (clinical trials) of nanomedicine is riddled with obstacles. The main challenges linked to the clinical translation of nanoparticles combating viral and bacterial infections are biological issues (e.g., antigenicity, immunotoxicity, and reticular-endothelial system recruitment), safety, biocompatibility, intellectual property, laws and regulations, and cost-effectiveness respect to traditional therapies. These challenges sometimes create an almost insurmountable breach between the nanoparticle and the patient.

Author Contributions: All authors have contributed equally. All authors have read and agreed to the published version of the manuscript.

Funding: This research was funded by the European Research Council through ERC-2015-AdG694160 (VERDI) grant.

Institutional Review Board Statement: Not applicable.

Informed Consent Statement: Not applicable.

Data Availability Statement: The data presented in this study are available on request from the corresponding author. Some data are not publicly available since some articles are not open access.

Acknowledgments: Figure 2,Figure 3, Figure 4 have been created with BioRender.com.

Conflicts of Interest: J.E. received travel grants from Pfizer and conference fees from Biomérieux and Heraeus. The funders had no role in the design of the study; in the collection, analyses, or interpretation of data; in the writing of the manuscript, or in the decision to publish the results.

\section{References}

1. Bloom, D.E.; Cadarette, D. Infectious Disease Threats in the Twenty-First Century: Strengthening the Global Response. Front. Immunol. 2019, 10, 549. [CrossRef] [PubMed]

2. The Top 10 Causes of Death. Available online: https://www.who.int/news-room/fact-sheets/detail/the-top-10-causes-of-death (accessed on 2 November 2020).

3. Christiansen, J. Global Infections by the Numbers. Available online: https://www.scientificamerican.com/article/globalinfections-by-the-numbers / (accessed on 2 November 2020).

4. Michael, C.A.; Dominey-Howes, D.; Labbate, M. The Antimicrobial Resistance Crisis: Causes, Consequences, and Management. Front. Public Health 2014, 2, 145. [CrossRef] [PubMed]

5. Uchil, R.R.; Kohli, G.S.; Katekhaye, V.M.; Swami, O.C. Strategies to Combat Antimicrobial Resistance. J. Clin. Diagn. Res. 2014, 8, ME01-04. [CrossRef] [PubMed]

6. Tinkle, S.; McNeil, S.E.; Mühlebach, S.; Bawa, R.; Borchard, G.; Barenholz, Y.C.; Tamarkin, L.; Desai, N. Nanomedicines: Addressing the Scientific and Regulatory Gap: Nanomedicines. Ann. N. Y. Acad. Sci. 2014, 1313, 35-56. [CrossRef] [PubMed]

7. Soares, S.; Sousa, J.; Pais, A.; Vitorino, C. Nanomedicine: Principles, Properties, and Regulatory Issues. Front. Chem. 2018, 6, 360. [CrossRef] [PubMed]

8. Hua, S.; Wu, S.Y. Editorial: Advances and Challenges in Nanomedicine. Front. Pharmacol. 2018, 9, 1397. [CrossRef] [PubMed]

9. Manzano, M.; Vallet-Regí, M. Mesoporous Silica Nanoparticles for Drug Delivery. Adv. Funct. Mater. 2020, 30, 1902634. [CrossRef]

10. Vallet-Regí, M.; Balas, F.; Arcos, D. Mesoporous Materials for Drug Delivery. Angew. Chem. Int. Ed. 2007, 46, 7548-7558. [CrossRef]

11. Paris, J.L.; Vallet-Regí, M. Mesoporous Silica Nanoparticles for Co-Delivery of Drugs and Nucleic Acids in Oncology: A Review. Pharmaceutics 2020, 12, 526. [CrossRef]

12. Martínez-Carmona, M.; Lozano, D.; Colilla, M.; Vallet-Regí, M. Lectin-Conjugated PH-Responsive Mesoporous Silica Nanoparticles for Targeted Bone Cancer Treatment. Acta Biomater. 2018, 65, 393-404. [CrossRef]

13. Yohan, D.; Chithrani, B.D. Applications of Nanoparticles in Nanomedicine. J. Biomed. Nanotechnol. 2014, 10, 2371-2392. [CrossRef] [PubMed]

14. Bawa, R. Regulating Nanomedicine-Can the FDA Handle It? Curr. Drug Deliv. 2011, 8, 227-234. [CrossRef] [PubMed]

15. Vallet-Regi, M.; Rámila, A.; del Real, R.P.; Pérez-Pariente, J. A New Property of MCM-41: Drug Delivery System. Chem. Mater. 2001, 13, 308-311. [CrossRef]

16. Ventola, C.L. The Nanomedicine Revolution: Part 1: Emerging Concepts. Pharm. Ther. 2012, 37, 512-525.

17. Gisbert-Garzarán, M.; Vallet-Regí, M. Influence of the Surface Functionalization on the Fate and Performance of Mesoporous Silica Nanoparticles. Nanomaterials 2020, 10, 916. [CrossRef]

18. Jeevanandam, J.; Barhoum, A.; Chan, Y.S.; Dufresne, A.; Danquah, M.K. Review on Nanoparticles and Nanostructured Materials: History, Sources, Toxicity and Regulations. Beilstein. J. Nanotechnol. 2018, 9, 1050-1074. [CrossRef] 
19. Boboc, M.; Curti, F.; Fleacă, A.M.; Jianu, M.L.; Roşu, A.-M.; Curutiu, C.; Lazar, V.; Chifiriuc, M.C.; Grumezescu, A.M. Preparation and Antimicrobial Activity of Inorganic Nanoparticles. In Nanostructures for Antimicrobial Therapy; Elsevier: Amsterdam, The Netherlands, 2017; pp. 325-340. ISBN 978-0-323-46152-8.

20. Zazo, H.; Colino, C.I.; Lanao, J.M. Current Applications of Nanoparticles in Infectious Diseases. J. Control. Release 2016, 224, 86-102. [CrossRef]

21. Lee, N.-Y.; Ko, W.-C.; Hsueh, P.-R. Nanoparticles in the Treatment of Infections Caused by Multidrug-Resistant Organisms. Front. Pharmacol. 2019, 10, 1153. [CrossRef]

22. Djurišić, A.B.; Leung, Y.H.; Ng, A.M.C.; Xu, X.Y.; Lee, P.K.H.; Degger, N.; Wu, R.S.S. Toxicity of Metal Oxide Nanoparticles: Mechanisms, Characterization, and Avoiding Experimental Artefacts. Small 2015, 11, 26-44. [CrossRef]

23. Vallet-Regí, M. Ordered Mesoporous Materials in the Context of Drug Delivery Systems and Bone Tissue Engineering. Chem.-Eur. J. 2006, 12, 5934-5943. [CrossRef]

24. Gisbert-Garzarán, M.; Manzano, M.; Vallet-Regí, M. Mesoporous Silica Nanoparticles for the Treatment of Complex Bone Diseases: Bone Cancer, Bone Infection and Osteoporosis. Pharmaceutics 2020, 12, 83. [CrossRef] [PubMed]

25. Vallet-Regí, M.; González, B.; Izquierdo-Barba, I. Nanomaterials as Promising Alternative in the Infection Treatment. Int. J. Mol. Sci. 2019, 20, 3806. [CrossRef] [PubMed]

26. Vallet-Regí, M. Bioceramics: From Bone Substitutes to Nanoparticles for Drug Delivery. Pure Appl. Chem. 2019, 91, 687-706. [CrossRef] [PubMed]

27. Mitragotri, S.; Stayton, P. Organic Nanoparticles for Drug Delivery and Imaging. MRS Bull. 2014, 39, 219-223. [CrossRef]

28. Aparna, V.A.; Biswas, R.; Jayakumar, R. Targeted nanoparticles for treating infectious diseases. In Biomimetic Nanoengineered Materials for Advanced Drug Delivery; Elsevier: Amsterdam, The Netherlands, 2019; pp. 169-185. ISBN 978-0-12-814944-7.

29. Schütz, C.A.; Juillerat-Jeanneret, L.; Mueller, H.; Lynch, I.; Riediker, M. Therapeutic Nanoparticles in Clinics and under Clinical Evaluation. Nanomedicine 2013, 8, 449-467. [CrossRef]

30. Simonsen, J.B. A Liposome-Based Size Calibration Method for Measuring Microvesicles by Flow Cytometry. J. Thromb. Haemost. 2016, 14, 186-190. [CrossRef]

31. Singh, L.; Kruger, H.G.; Maguire, G.E.M.; Govender, T.; Parboosing, R. The Role of Nanotechnology in the Treatment of Viral Infections. Ther. Adv. Infect. Dis. 2017, 4, 105-131. [CrossRef]

32. Abbasi, E.; Aval, S.F.; Akbarzadeh, A.; Milani, M.; Nasrabadi, H.T.; Joo, S.W.; Hanifehpour, Y.; Nejati-Koshki, K.; Pashaei-Asl, R. Dendrimers: Synthesis, Applications, and Properties. Nanoscale Res. Lett. 2014, 9, 247. [CrossRef]

33. Ghasemiyeh, P.; Mohammadi-Samani, S. Solid Lipid Nanoparticles and Nanostructured Lipid Carriers as Novel Drug Delivery Systems: Applications, Advantages and Disadvantages. Res. Pharm. Sci. 2018, 13, 288-303. [CrossRef]

34. Moghimi, R.; Aliahmadi, A.; McClements, D.J.; Rafati, H. Nanoemulsification of Salvia officinalis Essential Oil; The Impact on the Antibacterial Activity in Liquid and Vapour Phase. J. Bionanosci. 2017, 11, 80-86. [CrossRef]

35. Klepser, M.E. Socioeconomic Impact of Seasonal (Epidemic) Influenza and the Role of Over-the-Counter Medicines. Drugs 2014, 74, 1467-1479. [CrossRef] [PubMed]

36. Troeger, C.; Forouzanfar, M.; Rao, P.C.; Khalil, I.; Brown, A.; Swartz, S.; Fullman, N.; Mosser, J.; Thompson, R.L.; Reiner, R.C.; et al. Estimates of the Global, Regional, and National Morbidity, Mortality, and Aetiologies of Lower Respiratory Tract Infections in 195 Countries: A Systematic Analysis for the Global Burden of Disease Study 2015. Lancet Infect. Dis. 2017, 17, 1133-1161. [CrossRef]

37. Giraud-Gatineau, A.; Colson, P.; Jimeno, M.-T.; Zandotti, C.; Ninove, L.; Boschi, C.; Lagier, J.-C.; La Scola, B.; Chaudet, H.; Raoult, D. Comparison of Mortality Associated with Respiratory Viral Infections between December 2019 and March 2020 with That of the Previous Year in Southeastern France. Int. J. Infect. Dis. 2020, 96, 154-156. [CrossRef] [PubMed]

38. Al-Halifa, S.; Gauthier, L.; Arpin, D.; Bourgault, S.; Archambault, D. Nanoparticle-Based Vaccines Against Respiratory Viruses. Front. Immunol. 2019, 10, 22. [CrossRef] [PubMed]

39. Li, Y.; Lin, Z.; Zhao, M.; Xu, T.; Wang, C.; Hua, L.; Wang, H.; Xia, H.; Zhu, B. Silver Nanoparticle Based Codelivery of Oseltamivir to Inhibit the Activity of the H1N1 Influenza Virus through ROS-Mediated Signaling Pathways. ACS Appl. Mater. Interfaces 2016, 8, 24385-24393. [CrossRef]

40. Lin, Z.; Li, Y.; Guo, M.; Xu, T.; Wang, C.; Zhao, M.; Wang, H.; Chen, T.; Zhu, B. The Inhibition of H1N1 Influenza Virus-Induced Apoptosis by Silver Nanoparticles Functionalized with Zanamivir. RSC Adv. 2017, 7, 742-750. [CrossRef]

41. Papp, I.; Sieben, C.; Ludwig, K.; Roskamp, M.; Böttcher, C.; Schlecht, S.; Herrmann, A.; Haag, R. Inhibition of Influenza Virus Infection by Multivalent Sialic-Acid-Functionalized Gold Nanoparticles. Small 2010, 6, 2900-2906. [CrossRef]

42. Hendricks, G.L.; Weirich, K.L.; Viswanathan, K.; Li, J.; Shriver, Z.H.; Ashour, J.; Ploegh, H.L.; Kurt-Jones, E.A.; Fygenson, D.K.; Finberg, R.W.; et al. Sialylneolacto- N -Tetraose c (LSTc)-Bearing Liposomal Decoys Capture Influenza a Virus. J. Biol. Chem. 2013, 288, 8061-8073. [CrossRef]

43. Lin, Z.; Li, Y.; Guo, M.; Xiao, M.; Wang, C.; Zhao, M.; Xu, T.; Xia, Y.; Zhu, B. Inhibition of H1N1 Influenza Virus by Selenium Nanoparticles Loaded with Zanamivir through P38 and JNK Signaling Pathways. RSC Adv. 2017, 7, 35290-35296. [CrossRef]

44. Li, Y.; Lin, Z.; Guo, M.; Zhao, M.; Xia, Y.; Wang, C.; Xu, T.; Zhu, B. Inhibition of H1N1 Influenza Virus-Induced Apoptosis by Functionalized Selenium Nanoparticles with Amantadine through ROS-Mediated AKT Signaling Pathways. Int. J. Nanomed. 2018, 13, 2005-2016. [CrossRef] 
45. Lin, Z.; Li, Y.; Gong, G.; Xia, Y.; Wang, C.; Chen, Y.; Hua, L.; Zhong, J.; Tang, Y.; Liu, X.; et al. Restriction of H1N1 Influenza Virus Infection by Selenium Nanoparticles Loaded with Ribavirin via Resisting Caspase-3 Apoptotic Pathway. Int. J. Nanomed. 2018, 13, 5787-5797. [CrossRef]

46. Li, Y.; Lin, Z.; Guo, M.; Xia, Y.; Zhao, M.; Wang, C.; Xu, T.; Chen, T.; Zhu, B. Inhibitory Activity of Selenium Nanoparticles Functionalized with Oseltamivir on H1N1 Influenza Virus. Int. J. Nanomed. 2017, 12, 5733-5743. [CrossRef]

47. Kim, J.; Yeom, M.; Lee, T.; Kim, H.-O.; Na, W.; Kang, A.; Lim, J.-W.; Park, G.; Park, C.; Song, D.; et al. Porous Gold Nanoparticles for Attenuating Infectivity of Influenza a Virus. J. Nanobiotechnol. 2020, 18, 54. [CrossRef] [PubMed]

48. Sametband, M.; Shukla, S.; Meningher, T.; Hirsh, S.; Mendelson, E.; Sarid, R.; Gedanken, A.; Mandelboim, M. Effective Multi-Strain Inhibition of Influenza Virus by Anionic Gold Nanoparticles. Med. Chem. Commun. 2011, 2, 421. [CrossRef]

49. Levina, A.S.; Repkova, M.N.; Mazurkova, N.A.; Zarytova, V.F. Nanoparticle-Mediated Nonviral DNA Delivery for Effective Inhibition of Influenza a Viruses in Cells. IEEE Trans. Nanotechnol. 2016, 15, 248-254. [CrossRef]

50. Ghaffari, H.; Tavakoli, A.; Moradi, A.; Tabarraei, A.; Bokharaei-Salim, F.; Zahmatkeshan, M.; Farahmand, M.; Javanmard, D.; Kiani, S.J.; Esghaei, M.; et al. Inhibition of H1N1 Influenza Virus Infection by Zinc Oxide Nanoparticles: Another Emerging Application of Nanomedicine. J. Biomed. Sci. 2019, 26, 70. [CrossRef]

51. Wang, C.-Z.; Li, W.-J.; Tao, R.; Ye, J.-Z.; Zhang, H.-Y. Antiviral Activity of a Nanoemulsion of Polyprenols from Ginkgo Leaves against Influenza a H3N2 and Hepatitis B Virus in Vitro. Molecules 2015, 20, 5137-5151. [CrossRef]

52. Morris, D.; Ansar, M.; Speshock, J.; Ivanciuc, T.; Qu, Y.; Casola, A.; Garofalo, R. Antiviral and Immunomodulatory Activity of Silver Nanoparticles in Experimental RSV Infection. Viruses 2019, 11, 732. [CrossRef]

53. Yang, X.X.; Li, C.M.; Huang, C.Z. Curcumin Modified Silver Nanoparticles for Highly Efficient Inhibition of Respiratory Syncytial Virus Infection. Nanoscale 2016, 8, 3040-3048. [CrossRef]

54. Cagno, V.; Andreozzi, P.; D’Alicarnasso, M.; Jacob Silva, P.; Mueller, M.; Galloux, M.; Le Goffic, R.; Jones, S.T.; Vallino, M.; Hodek, J.; et al. Broad-Spectrum Non-Toxic Antiviral Nanoparticles with a Virucidal Inhibition Mechanism. Nature Mater. 2018, 17, 195-203. [CrossRef]

55. Osminkina, L.A.; Timoshenko, V.Y.; Shilovsky, I.P.; Kornilaeva, G.V.; Shevchenko, S.N.; Gongalsky, M.B.; Tamarov, K.P.; Abramchuk, S.S.; Nikiforov, V.N.; Khaitov, M.R.; et al. Porous Silicon Nanoparticles as Scavengers of Hazardous Viruses. J. Nanopart. Res. 2014, 16, 2430. [CrossRef]

56. Huang, X.; Li, M.; Xu, Y.; Zhang, J.; Meng, X.; An, X.; Sun, L.; Guo, L.; Shan, X.; Ge, J.; et al. Novel Gold Nanorod-Based HR1 Peptide Inhibitor for Middle East Respiratory Syndrome Coronavirus. ACS Appl. Mater. Interfaces 2019, 11, 19799-19807. [CrossRef]

57. Gurunathan, S.; Qasim, M.; Choi, Y.; Do, J.T.; Park, C.; Hong, K.; Kim, J.-H.; Song, H. Antiviral Potential of Nanoparticles-Can Nanoparticles Fight Against Coronaviruses? Nanomaterials 2020, 10, 1645. [CrossRef]

58. COVID-19 Map. Available online: https:/ / coronavirus.jhu.edu/map.html (accessed on 3 November 2020).

59. Medhi, R.; Srinoi, P.; Ngo, N.; Tran, H.-V.; Lee, T.R. Nanoparticle-Based Strategies to Combat COVID-19. ACS Appl. Nano Mater. 2020, 3, 8557-8580. [CrossRef]

60. Aydemir, D.; Ulusu, N.N. Correspondence: Angiotensin-Converting Enzyme 2 Coated Nanoparticles Containing Respiratory Masks, Chewing Gums and Nasal Filters May Be Used for Protection against COVID-19 Infection. Travel. Med. Infect. Dis. 2020, 37, 101697. [CrossRef] [PubMed]

61. Bellido-Blasco, J.B.; Arnedo-Pena, A. Epidemiology of Infectious Diarrhea. In Encyclopedia of Environmental Health; Elsevier: Amsterdam, The Netherlands, 2011; pp. 659-671. ISBN 978-0-444-63952-3.

62. Broglie, J.J.; Alston, B.; Yang, C.; Ma, L.; Adcock, A.F.; Chen, W.; Yang, L. Antiviral Activity of Gold/Copper Sulfide Core/Shell Nanoparticles against Human Norovirus Virus-Like Particles. PLoS ONE 2015, 10, e0141050. [CrossRef]

63. Li, Z.; Cui, K.; Wang, H.; Liu, F.; Huang, K.; Duan, Z.; Wang, F.; Shi, D.; Liu, Q. A Milk-Based Self-Assemble Rotavirus VP6-Ferritin Nanoparticle Vaccine Elicited Protection against the Viral Infection. J. Nanobiotechnol. 2019, 17, 13. [CrossRef]

64. Heinimäki, S.; Hankaniemi, M.M.; Sioofy-Khojine, A.-B.; Laitinen, O.H.; Hyöty, H.; Hytönen, V.P.; Vesikari, T.; Blazevic, V. Combination of Three Virus-Derived Nanoparticles as a Vaccine against Enteric Pathogens; Enterovirus, Norovirus and Rotavirus. Vaccine 2019, 37, 7509-7518. [CrossRef]

65. Lysenko, V.; Lozovski, V.; Lokshyn, M.; Gomeniuk, Y.V.; Dorovskih, A.; Rusinchuk, N.; Pankivska, Y.; Povnitsa, O.; Zagorodnya, S.; Tertykh, V.; et al. Nanoparticles as Antiviral Agents against Adenoviruses. Adv. Nat. Sci. Nanosci. Nanotechnol. $2018,9,025021$. [CrossRef]

66. Baun, A.; Hansen, S.F. Environmental Challenges for Nanomedicine. Nanomedicine 2008, 3, 605-608. [CrossRef]

67. Mahapatra, I.; Clark, J.R.A.; Dobson, P.J.; Owen, R.; Lynch, I.; Lead, J.R. Expert Perspectives on Potential Environmental Risks from Nanomedicines and Adequacy of the Current Guideline on Environmental Risk Assessment. Environ. Sci.: Nano 2018, 5 , 1873-1889. [CrossRef]

68. Sexually Transmitted Infections (STIs). Available online: https://www.who.int/news-room/fact-sheets/detail/sexuallytransmitted-infections-(stis) (accessed on 4 November 2020).

69. Nijmeijer, B.M.; Koopsen, J.; Schinkel, J.; Prins, M.; Geijtenbeek, T.B. Sexually Transmitted Hepatitis C Virus Infections: Current Trends, and Recent Advances in Understanding the Spread in Men Who Have Sex with Men. J. Int. AIDS Soc. 2019, 22 (Suppl. 6), e25348. [CrossRef] 
70. Global Statistics. Available online: https://www.hiv.gov/hiv-basics/overview/data-and-trends/global-statistics (accessed on 16 November 2020).

71. Prokofjeva, M.M.; Kochetkov, S.N.; Prassolov, V.S. Therapy of HIV Infection: Current Approaches and Prospects. Acta Nat. 2016, 8, 23-32. [CrossRef]

72. HIV Treatment: The Basics. Available online: https://hivinfo.nih.gov/understanding-hiv/fact-sheets/hiv-treatment-basics (accessed on 16 November 2020).

73. Zdanowicz, M.M. The Pharmacology of HIV Drug Resistance. Am. J. Pharm. Educ. 2006, 70, 100. [CrossRef]

74. Sun, R.W.-Y.; Chen, R.; Chung, N.P.-Y.; Ho, C.-M.; Lin, C.-L.S.; Che, C.-M. Silver Nanoparticles Fabricated in Hepes Buffer Exhibit Cytoprotective Activities toward HIV-1 Infected Cells. Chem. Commun. 2005, 5059. [CrossRef]

75. Rosemary Bastian, A.; Nangarlia, A.; Bailey, L.D.; Holmes, A.; Kalyana Sundaram, R.V.; Ang, C.; Moreira, D.R.M.; Freedman, K.; Duffy, C.; Contarino, M.; et al. Mechanism of Multivalent Nanoparticle Encounter with HIV-1 for Potency Enhancement of Peptide Triazole Virus Inactivation. J. Biol. Chem. 2015, 290, 529-543. [CrossRef]

76. Di Gianvincenzo, P.; Marradi, M.; Martínez-Ávila, O.M.; Bedoya, L.M.; Alcamí, J.; Penadés, S. Gold Nanoparticles Capped with Sulfate-Ended Ligands as Anti-HIV Agents. Bioorg. Med. Chem. Lett. 2010, 20, 2718-2721. [CrossRef]

77. Jaramillo-Ruiz, D.; De La Mata, F.J.; Gómez, R.; Correa-Rocha, R.; Muñoz-Fernández, M.Á. Nanotechnology as a New Therapeutic Approach to Prevent the HIV-Infection of Treg Cells. PLoS ONE 2016, 11, e0145760. [CrossRef]

78. Parboosing, R.; Chonco, L.; de la Mata, F.J.; Govender, T.; Maguire, G.E.; Kruger, H.G. Potential Inhibition of HIV-1 Encapsidation by Oligoribonucleotide-Dendrimer Nanoparticle Complexes. Int. J. Nanomed. 2017, 12, 317-325. [CrossRef]

79. Jayant, R.; Atluri, V.; Agudelo, M.; Sagar, V.; Kaushik, A.; Nair, M. Sustained-Release NanoART Formulation for The Treatment of NeuroAIDS. Int. J. Nanomed. 2015, 10, 1077. [CrossRef]

80. Smith, K.A. Activation of HIV-1 with Nanoparticle-Packaged Small Molecule Protein Phosphatase-1-Targeting Compound. Sci. Pharm. 2015, 83, 535-548. [CrossRef] [PubMed]

81. Jiang, Y.; Cao, S.; Bright, D.K.; Bever, A.M.; Blakney, A.K.; Suydam, I.T.; Woodrow, K.A. Nanoparticle-Based ARV Drug Combinations for Synergistic Inhibition of Cell-Free and Cell-Cell HIV Transmission. Mol. Pharm. 2015, 12, 4363-4374. [CrossRef]

82. Chaowanachan, T.; Krogstad, E.; Ball, C.; Woodrow, K.A. Drug Synergy of Tenofovir and Nanoparticle-Based Antiretrovirals for HIV Prophylaxis. PLoS ONE 2013, 8, e61416. [CrossRef]

83. de Souza e Silva, J.M.; Hanchuk, T.D.M.; Santos, M.I.; Kobarg, J.; Bajgelman, M.C.; Cardoso, M.B. Viral Inhibition Mechanism Mediated by Surface-Modified Silica Nanoparticles. ACS Appl. Mater. Interfaces 2016, 8, 16564-16572. [CrossRef]

84. Bromberg, L.; Bromberg, D.J.; Hatton, T.A.; Bandín, I.; Concheiro, A.; Alvarez-Lorenzo, C. Antiviral Properties of Polymeric Aziridine- and Biguanide-Modified Core-Shell Magnetic Nanoparticles. Langmuir 2012, 28, 4548-4558. [CrossRef]

85. Baram-Pinto, D.; Shukla, S.; Perkas, N.; Gedanken, A.; Sarid, R. Inhibition of Herpes Simplex Virus Type 1 Infection by Silver Nanoparticles Capped with Mercaptoethane Sulfonate. Bioconjug. Chem. 2009, 20, 1497-1502. [CrossRef]

86. Lima, T.; Feitosa, R.; dos Santos-Silva, E.; dos Santos-Silva, A.; Siqueira, E.; Machado, P.; Cornélio, A.; do Egito, E.; FernandesPedrosa, M.; Farias, K.; et al. Improving Encapsulation of Hydrophilic Chloroquine Diphosphate into Biodegradable Nanoparticles: A Promising Approach against Herpes Virus Simplex-1 Infection. Pharmaceutics 2018, 10, 255. [CrossRef]

87. Al-Dhubiab, B.E.; Nair, A.B.; Kumria, R.; Attimarad, M.; Harsha, S. Formulation and Evaluation of Nano Based Drug Delivery System for the Buccal Delivery of Acyclovir. Colloids Surf. B Biointerfaces 2015, 136, 878-884. [CrossRef]

88. Palliser, D.; Chowdhury, D.; Wang, Q.-Y.; Lee, S.J.; Bronson, R.T.; Knipe, D.M.; Lieberman, J. An SiRNA-Based Microbicide Protects Mice from Lethal Herpes Simplex Virus 2 Infection. Nature 2006, 439, 89-94. [CrossRef]

89. Woodrow, K.A.; Cu, Y.; Booth, C.J.; Saucier-Sawyer, J.K.; Wood, M.J.; Saltzman, W.M. Intravaginal Gene Silencing Using Biodegradable Polymer Nanoparticles Densely Loaded with Small-Interfering RNA. Nat. Mater. 2009, 8, 526-533. [CrossRef]

90. Ramyadevi, D.; Rajan, K.S.; Vedhahari, B.N.; Ruckmani, K.; Subramanian, N. Heterogeneous Polymer Composite Nanoparticles Loaded in Situ Gel for Controlled Release Intra-Vaginal Therapy of Genital Herpes. Colloids Surf. B Biointerfaces 2016, 146, 260-270. [CrossRef] [PubMed]

91. Lu, L.; Sun, R.W.-Y.; Chen, R.; Hui, C.-K.; Ho, C.-M.; Luk, J.M.; Lau, G.K.K.; Che, C.-M. Silver Nanoparticles Inhibit Hepatitis B Virus Replication. Antivir. Ther. 2008, 13, 253-262. [PubMed]

92. Wang, J.; Feng, S.-S.; Wang, S.; Chen, Z. Evaluation of Cationic Nanoparticles of Biodegradable Copolymers as SiRNA Delivery System for Hepatitis B Treatment. Int. J. Pharm. 2010, 400, 194-200. [CrossRef] [PubMed]

93. Zhang, J.; Mulvenon, A.; Makarov, E.; Wagoner, J.; Knibbe, J.; Kim, J.O.; Osna, N.; Bronich, T.K.; Poluektova, L.Y. Antiviral Peptide Nanocomplexes as a Potential Therapeutic Modality for HIV/HCV Co-Infection. Biomaterials 2013, 34, 3846-3857. [CrossRef] [PubMed]

94. Zhang, J.; Garrison, J.C.; Poluektova, L.Y.; Bronich, T.K.; Osna, N.A. Liver-Targeted Antiviral Peptide Nanocomplexes as Potential Anti-HCV Therapeutics. Biomaterials 2015, 70, 37-47. [CrossRef]

95. Katas, H.; Alpar, H.O. Development and Characterisation of Chitosan Nanoparticles for SiRNA Delivery. J. Control. Release 2006, 115, 216-225. [CrossRef]

96. Torrecilla, J.; del Pozo-Rodríguez, A.; Apaolaza, P.S.; Solinís, M.Á.; Rodríguez-Gascón, A. Solid Lipid Nanoparticles as Non-Viral Vector for the Treatment of Chronic Hepatitis C by RNA Interference. Int. J. Pharm. 2015, 479, 181-188. [CrossRef]

97. Hang, X.; Peng, H.; Song, H.; Qi, Z.; Miao, X.; Xu, W. Antiviral Activity of Cuprous Oxide Nanoparticles against Hepatitis C Virus in Vitro. J. Virol. Methods 2015, 222, 150-157. [CrossRef] 
98. Ryoo, S.-R.; Jang, H.; Kim, K.-S.; Lee, B.; Kim, K.B.; Kim, Y.-K.; Yeo, W.-S.; Lee, Y.; Kim, D.-E.; Min, D.-H. Functional Delivery of DNAzyme with Iron Oxide Nanoparticles for Hepatitis C Virus Gene Knockdown. Biomaterials 2012, 33, 2754-2761. [CrossRef]

99. Ahmed-Belkacem, A.; Ahnou, N.; Barbotte, L.; Wychowski, C.; Pallier, C.; Brillet, R.; Pohl, R.; Pawlotsky, J. Silibinin and Related Compounds Are Direct Inhibitors of Hepatitis C Virus RNA-Dependent RNA Polymerase. Gastroenterology 2010, 138, 1112-1122. [CrossRef]

100. Delaviz, N.; Gill, P.; Ajami, A.; Aarabi, M. Aptamer-Conjugated Magnetic Nanoparticles for the Efficient Removal of HCV Particles from Human Plasma Samples. RSC Adv. 2015, 5, 79433-79439. [CrossRef]

101. Mathew, J., Jr.; Sapra, A. Herpes Simplex Type 2. In StatPearls; StatPearls Publishing: Treasure Island, FL, USA, 2020.

102. Rupar, M.J.; Golusinski, P.; Golusinski, W.; Masternak, M.M. Human Papillomavirus and the Use of Nanoparticles for Immunotherapy in HPV-Related Cancer: A Review. Rep. Pract. Oncol. Radiother. 2019, 24, 544-550. [CrossRef]

103. Gilson, R.; Brook, M.G. Hepatitis A, B, and C. Sexually Transmitted Infections 2006, 82, iv35-iv39. [CrossRef] [PubMed]

104. Wang, B.; He, X.; Zhang, Z.; Zhao, Y.; Feng, W. Metabolism of Nanomaterials in Vivo: Blood Circulation and Organ Clearance. Acc. Chem. Res. 2013, 46, 761-769. [CrossRef] [PubMed]

105. Harris, J.B.; LaRocque, R.C.; Qadri, F.; Ryan, E.T.; Calderwood, S.B. Cholera. Lancet 2012, 379, 2466-2476. [CrossRef]

106. Sarwar, S.; Ali, A.; Pal, M.; Chakrabarti, P. Zinc Oxide Nanoparticles Provide Anti-Cholera Activity by Disrupting the Interaction of Cholera Toxin with the Human GM1 Receptor. J. Biol. Chem. 2017, 292, 18303-18311. [CrossRef]

107. Rajput, V.D.; Minkina, T.M.; Behal, A.; Sushkova, S.N.; Mandzhieva, S.; Singh, R.; Gorovtsov, A.; Tsitsuashvili, V.S.; Purvis, W.O.; Ghazaryan, K.A.; et al. Effects of Zinc-Oxide Nanoparticles on Soil, Plants, Animals and Soil Organisms: A Review. Environ. Nanotechnol. Monit. Manag. 2018, 9, 76-84. [CrossRef]

108. Das, S.; Angsantikul, P.; Le, C.; Bao, D.; Miyamoto, Y.; Gao, W.; Zhang, L.; Eckmann, L. Neutralization of Cholera Toxin with Nanoparticle Decoys for Treatment of Cholera. PLoS Negl. Trop. Dis. 2018, 12, e0006266. [CrossRef]

109. Yang, R. Plague: Recognition, Treatment, and Prevention. J. Clin. Microbiol. 2018, 56. [CrossRef]

110. Tao, P.; Mahalingam, M.; Rao, V.B. Highly Effective Soluble and Bacteriophage T4 Nanoparticle Plague Vaccines Against Yersinia pestis. In Vaccine Design; Thomas, S., Ed.; Methods in Molecular Biology; Springer: New York, NY, USA, 2016; Volume 1403, pp. 499-518. ISBN 978-1-4939-3385-3.

111. Barberis, I.; Bragazzi, N.L.; Galluzzo, L.; Martini, M. The History of Tuberculosis: From the First Historical Records to the Isolation of Koch's Bacillus. J. Prev. Med. Hyg. 2017, 58, E9-E12.

112. MacNeil, A.; Glaziou, P.; Sismanidis, C.; Date, A.; Maloney, S.; Floyd, K. Global Epidemiology of Tuberculosis and Progress Toward Meeting Global Targets-Worldwide, 2018. MMWR Morb. Mortal. Wkly. Rep. 2020, 69, 281-285. [CrossRef] [PubMed]

113. World Health Organization. Global Tuberculosis Report 2019; World Health Organization: Geneva, Switzerland, 2019; ISBN 978-924-156571-4.

114. Tăbăran, A.-F.; Matea, C.T.; Mocan, T.; Tăbăran, A.; Mihaiu, M.; Iancu, C.; Mocan, L. Silver Nanoparticles for the Therapy of Tuberculosis. Int. J. Nanomed. 2020, 15, 2231-2258. [CrossRef]

115. Estevez, H.; Palacios, A.; Gil, D.; Anguita, J.; Vallet-Regi, M.; González, B.; Prados-Rosales, R.; Luque-Garcia, J.L. Antimycobacterial Effect of Selenium Nanoparticles on Mycobacterium Tuberculosis. Front. Microbiol. 2020, 11, 800. [CrossRef] [PubMed]

116. Ramalingam, V.; Sundaramahalingam, S.; Rajaram, R. Size-Dependent Antimycobacterial Activity of Titanium Oxide Nanoparticles against Mycobacterium Tuberculosis. J. Mater. Chem. B 2019, 7, 4338-4346. [CrossRef]

117. de Faria, T.J.; Roman, M.; de Souza, N.M.; De Vecchi, R.; de Assis, J.V.; dos Santos, A.L.G.; Bechtold, I.H.; Winter, N.; Soares, M.J.; Silva, L.P.; et al. An Isoniazid Analogue Promotes Mycobacterium Tuberculosis-Nanoparticle Interactions and Enhances Bacterial Killing by Macrophages. Antimicrob. Agents Chemother. 2012, 56, 2259-2267. [CrossRef]

118. Centers for Disease Control and Prevention (USA). Antibiotic Resistance Threats in the United States; Department of Health and Human Services, CDC: Atlanta, GA, USA, 2019.

119. Tacconelli, E. Global Priority List of Antibiotic-Resistant Bacteria to Guide Research, Discovery, and Development of New Antibiotics; World Health Organization: Geneva, Switzerland, 2017; Volume 27, pp. 318-327.

120. Reygaert, W.C. An Overview of the Antimicrobial Resistance Mechanisms of Bacteria. AIMS Microbiol 2018, 4, 482-501. [CrossRef] [PubMed]

121. Huh, A.J.; Kwon, Y.J. “Nanoantibiotics”: A New Paradigm for Treating Infectious Diseases Using Nanomaterials in the Antibiotics Resistant Era. J. Control. Release 2011, 156, 128-145. [CrossRef]

122. Cavassin, E.D.; de Figueiredo, L.F.P.; Otoch, J.P.; Seckler, M.M.; de Oliveira, R.A.; Franco, F.F.; Marangoni, V.S.; Zucolotto, V.; Levin, A.S.S.; Costa, S.F. Comparison of Methods to Detect the in Vitro Activity of Silver Nanoparticles (AgNP) against Multidrug Resistant Bacteria. J. Nanobiotechnol. 2015, 13, 64. [CrossRef]

123. Zaidi, S.; Misba, L.; Khan, A.U. Nano-Therapeutics: A Revolution in Infection Control in Post Antibiotic Era. Nanomed. Nanotechnol. Biol. Med. 2017, 13, 2281-2301. [CrossRef]

124. Rudramurthy, G.; Swamy, M.; Sinniah, U.; Ghasemzadeh, A. Nanoparticles: Alternatives Against Drug-Resistant Pathogenic Microbes. Molecules 2016, 21, 836. [CrossRef]

125. Hemeg, H. Nanomaterials for Alternative Antibacterial Therapy. Int. J. Nanomed. 2017, 12, 8211-8225. [CrossRef]

126. Chen, C.-W.; Hsu, C.-Y.; Lai, S.-M.; Syu, W.-J.; Wang, T.-Y.; Lai, P.-S. Metal Nanobullets for Multidrug Resistant Bacteria and Biofilms. Adv. Drug Deliv. Rev. 2014, 78, 88-104. [CrossRef] [PubMed] 
127. Dizaj, S.M.; Lotfipour, F.; Barzegar-Jalali, M.; Zarrintan, M.H.; Adibkia, K. Antimicrobial Activity of the Metals and Metal Oxide Nanoparticles. Mater. Sci. Eng. C 2014, 44, 278-284. [CrossRef]

128. Chatterjee, A.K.; Chakraborty, R.; Basu, T. Mechanism of Antibacterial Activity of Copper Nanoparticles. Nanotechnology 2014, 25, 135101. [CrossRef] [PubMed]

129. Feng, Q.L.; Wu, J.; Chen, G.Q.; Cui, F.Z.; Kim, T.N.; Kim, J.O. A Mechanistic Study of the Antibacterial Effect of Silver Ions on Escherichia Coli and Staphylococcus Aureus. J. Biomed. Mater. Res. 2000, 52, 662-668. [CrossRef]

130. Smetana, A.B.; Klabunde, K.J.; Marchin, G.R.; Sorensen, C.M. Biocidal Activity of Nanocrystalline Silver Powders and Particles. Langmuir 2008, 24, 7457-7464. [CrossRef] [PubMed]

131. Panáček, A.; Kvítek, L.; Prucek, R.; Kolář, M.; Večeřová, R.; Pizúrová, N.; Sharma, V.K.; Nevěčná, T.; Zbořil, R. Silver Colloid Nanoparticles: Synthesis, Characterization, and Their Antibacterial Activity. J. Phys. Chem. B 2006, 110, 16248-16253. [CrossRef]

132. Nanda, A.; Saravanan, M. Biosynthesis of Silver Nanoparticles from Staphylococcus Aureus and Its Antimicrobial Activity against MRSA and MRSE. Nanomed. Nanotechnol. Biol. Med. 2009, 5, 452-456. [CrossRef]

133. Sondi, I.; Salopek-Sondi, B. Silver Nanoparticles as Antimicrobial Agent: A Case Study on E. Coli as a Model for Gram-Negative Bacteria. J. Colloid Interface Sci. 2004, 275, 177-182. [CrossRef]

134. Kim, J.S.; Kuk, E.; Yu, K.N.; Kim, J.-H.; Park, S.J.; Lee, H.J.; Kim, S.H.; Park, Y.K.; Park, Y.H.; Hwang, C.-Y.; et al. Antimicrobial Effects of Silver Nanoparticles. Nanomed. Nanotechnol. Biol. Med. 2007, 3, 95-101. [CrossRef] [PubMed]

135. Sharma, V.K.; Yngard, R.A.; Lin, Y. Silver Nanoparticles: Green Synthesis and Their Antimicrobial Activities. Adv. Colloid Interface Sci. 2009, 145, 83-96. [CrossRef] [PubMed]

136. Gil-Tomás, J.; Tubby, S.; Parkin, I.P.; Narband, N.; Dekker, L.; Nair, S.P.; Wilson, M.; Street, C. Lethal Photosensitisation of Staphylococcus Aureus Using a Toluidine Blue O-Tiopronin-Gold Nanoparticle Conjugate. J. Mater. Chem. 2007, 17, 3739. [CrossRef]

137. Perni, S.; Piccirillo, C.; Pratten, J.; Prokopovich, P.; Chrzanowski, W.; Parkin, I.P.; Wilson, M. The Antimicrobial Properties of Light-Activated Polymers Containing Methylene Blue and Gold Nanoparticles. Biomaterials 2009, 30, 89-93. [CrossRef] [PubMed]

138. MubarakAli, D.; Thajuddin, N.; Jeganathan, K.; Gunasekaran, M. Plant Extract Mediated Synthesis of Silver and Gold Nanoparticles and Its Antibacterial Activity against Clinically Isolated Pathogens. Colloids Surf. B Biointerfaces 2011, 85, 360-365. [CrossRef]

139. Li, X.; Robinson, S.M.; Gupta, A.; Saha, K.; Jiang, Z.; Moyano, D.F.; Sahar, A.; Riley, M.A.; Rotello, V.M. Functional Gold Nanoparticles as Potent Antimicrobial Agents against Multi-Drug-Resistant Bacteria. ACS Nano 2014, 8, 10682-10686. [CrossRef]

140. Matsunaga, T.; Tomoda, R.; Nakajima, T.; Nakamura, N.; Komine, T. Continuous-Sterilization System That Uses Photosemiconductor Powders. Appl. Environ. Microbiol. 1988, 54, 1330-1333. [CrossRef]

141. Kim, B.; Kim, D.; Cho, D.; Cho, S. Bactericidal Effect of $\mathrm{TiO}_{2}$ Photocatalyst on Selected Food-Borne Pathogenic Bacteria. Chemosphere 2003, 52, 277-281. [CrossRef]

142. Chawengkijwanich, C.; Hayata, Y. Development of $\mathrm{TiO}_{2}$ Powder-Coated Food Packaging Film and Its Ability to Inactivate Escherichia Coli in Vitro and in Actual Tests. Int. J. Food Microbiol. 2008, 123, 288-292. [CrossRef]

143. Jiang, W.; Mashayekhi, H.; Xing, B. Bacterial Toxicity Comparison between Nano- and Micro-Scaled Oxide Particles. Environ. Pollut. 2009, 157, 1619-1625. [CrossRef]

144. Jones, N.; Ray, B.; Ranjit, K.T.; Manna, A.C. Antibacterial Activity of ZnO Nanoparticle Suspensions on a Broad Spectrum of Microorganisms. FEMS Microbiol. Lett. 2008, 279, 71-76. [CrossRef]

145. Ghule, K.; Ghule, A.V.; Chen, B.-J.; Ling, Y.-C. Preparation and Characterization of ZnO Nanoparticles Coated Paper and Its Antibacterial Activity Study. Green Chem. 2006, 8, 1034. [CrossRef]

146. Cioffi, N.; Torsi, L.; Ditaranto, N.; Tantillo, G.; Ghibelli, L.; Sabbatini, L.; Bleve-Zacheo, T.; D’Alessio, M.; Zambonin, P.G.; Traversa, E. Copper Nanoparticle/Polymer Composites with Antifungal and Bacteriostatic Properties. Chem. Mater. 2005, 17, 5255-5262. [CrossRef]

147. Ruparelia, J.P.; Chatterjee, A.K.; Duttagupta, S.P.; Mukherji, S. Strain Specificity in Antimicrobial Activity of Silver and Copper Nanoparticles. Acta Biomater. 2008, 4, 707-716. [CrossRef]

148. Koper, O.B.; Klabunde, J.S.; Marchin, G.L.; Klabunde, K.J.; Stoimenov, P.; Bohra, L. Nanoscale Powders and Formulations with Biocidal Activity toward Spores and Vegetative Cells of Bacillus Species, Viruses, and Toxins. Curr. Microbiol. 2002, $44,49-55$. [CrossRef] [PubMed]

149. Krishnamoorthy, K.; Manivannan, G.; Kim, S.J.; Jeyasubramanian, K.; Premanathan, M. Antibacterial Activity of MgO Nanoparticles Based on Lipid Peroxidation by Oxygen Vacancy. J. Nanopart. Res. 2012, 14, 1063. [CrossRef]

150. Roy, A.; Gauri, S.S.; Bhattacharya, M.; Bhattacharya, J. Antimicrobial Activity of CaO Nanoparticles. J. Biomed. Nanotechnol. 2013, 9, 1570-1578. [CrossRef]

151. Sawai, J. Quantitative Evaluation of Antibacterial Activities of Metallic Oxide Powders ( $\mathrm{ZnO}, \mathrm{MgO}$ and CaO) by Conductimetric Assay. J. Microbiol. Methods 2003, 54, 177-182. [CrossRef]

152. Catauro, M.; Raucci, M.G.; de Gaetano, F.; Marotta, A. Antibacterial and Bioactive Silver-Containing $\mathrm{Na}_{2} \mathrm{O} \cdot \mathrm{CaO} \cdot 2 \mathrm{SiO}{ }_{2} \mathrm{Glass}$ Prepared by Sol-Gel Method. J. Mater. Sci. Mater. Med. 2004, 15, 831-837. [CrossRef]

153. Li, B.; Logan, B.E. Bacterial Adhesion to Glass and Metal-Oxide Surfaces. Colloids Surf. B Biointerfaces 2004, 36, 81-90. [CrossRef]

154. Prashanth, P.A.; Raveendra, R.S.; Hari Krishna, R.; Ananda, S.; Bhagya, N.P.; Nagabhushana, B.M.; Lingaraju, K.; Raja Naika, H. Synthesis, Characterizations, Antibacterial and Photoluminescence Studies of Solution Combustion-Derived $\alpha-\mathrm{Al}_{2} \mathrm{O}_{3} \mathrm{Nanoparti}_{-}$ cles. J. Asian Ceram. Soc. 2015, 3, 345-351. [CrossRef] 
155. Jastrzębska, A.M.; Radziun, E.; Rosłon, M.; Kunicki, A.R.; Olszyna, A.R.; Dudkiewicz-Wilczyńska, J.; Anuszewska, E.; Karwowska, E. In Vitro Assessment of Antibacterial Properties and Cytotoxicity of $\mathrm{Al}_{2} \mathrm{O}_{3}-\mathrm{Ag}$ Nanopowders. Adv. Appl. Ceram. 2011, 110, 353-359. [CrossRef]

156. Adams, L.K.; Lyon, D.Y.; Alvarez, P.J.J. Comparative Eco-Toxicity of Nanoscale $\mathrm{TiO}_{2}$, $\mathrm{SiO}_{2}$, and ZnO Water Suspensions. Water Res. 2006, 40, 3527-3532. [CrossRef] [PubMed]

157. Haydel, S.E.; Remenih, C.M.; Williams, L.B. Broad-Spectrum in Vitro Antibacterial Activities of Clay Minerals against AntibioticSusceptible and Antibiotic-Resistant Bacterial Pathogens. J. Antimicrob. Chemother. 2007, 61, 353-361. [CrossRef] [PubMed]

158. Suganya, P.; Vaseeharan, B.; Vijayakumar, S.; Balan, B.; Govindarajan, M.; Alharbi, N.S.; Kadaikunnan, S.; Khaled, J.M.; Benelli, G. Biopolymer Zein-Coated Gold Nanoparticles: Synthesis, Antibacterial Potential, Toxicity and Histopathological Effects against the Zika Virus Vector Aedes Aegypti. J. Photochem. Photobiol. B Biol. 2017, 173, 404-411. [CrossRef] [PubMed]

159. Yang, S.B.; Rabbani, M.M.; Ji, B.C.; Han, D.-W.; Lee, J.S.; Kim, J.W.; Yeum, J.H. Optimum Conditions for the Fabrication of Zein/Ag Composite Nanoparticles from Ethanol/ $\mathrm{H}_{2} \mathrm{O}$ Co-Solvents Using Electrospinning. Nanomaterials 2016, 6, 230. [CrossRef] [PubMed]

160. Bianchetti, M.G.; Simonetti, G.D.; Bettinelli, A. Body Fluids and Salt Metabolism—Part I. Ital. J. Pediatr. 2009, 35, 36. [CrossRef]

161. Lobo, V.; Patil, A.; Phatak, A.; Chandra, N. Free Radicals, Antioxidants and Functional Foods: Impact on Human Health. Pharm. Rev. 2010, 4, 118-126. [CrossRef]

162. Aguilera-Correa, J.-J.; Conde, A.; Arenas, M.-A.; de-Damborenea, J.-J.; Marin, M.; Doadrio, A.L.; Esteban, J. Bactericidal Activity of the Ti-13Nb-13Zr Alloy against Different Species of Bacteria Related with Implant Infection. Biomed. Mater. 2017, 12, 045022. [CrossRef]

163. Schrand, A.M.; Rahman, M.F.; Hussain, S.M.; Schlager, J.J.; Smith, D.A.; Syed, A.F. Metal-based Nanoparticles and Their Toxicity Assessment. WIREs Nanomed. Nanobiotechnol. 2010, 2, 544-568. [CrossRef]

164. Ding, L.; Liu, Z.; Aggrey, M.; Li, C.; Chen, J.; Tong, L. Nanotoxicity: The Toxicity Research Progress of Metal and Metal- Containing Nanoparticles. MRMC 2015, 15, 529-542. [CrossRef]

165. Ahghari, M.R.; Soltaninejad, V.; Maleki, A. Synthesis of Nickel Nanoparticles by a Green and Convenient Method as a Magnetic Mirror with Antibacterial Activities. Sci. Rep. 2020, 10, 12627. [CrossRef] [PubMed]

166. Jeyaraj Pandian, C.; Palanivel, R.; Dhanasekaran, S. Screening Antimicrobial Activity of Nickel Nanoparticles Synthesized Using Ocimum Sanctum Leaf Extract. J. Nanopart. 2016, 2016, 1-13. [CrossRef]

167. Bellio, P.; Luzi, C.; Mancini, A.; Cracchiolo, S.; Passacantando, M.; Di Pietro, L.; Perilli, M.; Amicosante, G.; Santucci, S.; Celenza, G. Cerium Oxide Nanoparticles as Potential Antibiotic Adjuvant. Effects of $\mathrm{CeO}_{2}$ Nanoparticles on Bacterial Outer Membrane Permeability. Biochim. Biophys. Acta (BBA)-Biomembr. 2018, 1860, 2428-2435. [CrossRef] [PubMed]

168. Vahdati, M.; Tohidi Moghadam, T. Synthesis and Characterization of Selenium Nanoparticles-Lysozyme Nanohybrid System with Synergistic Antibacterial Properties. Sci. Rep. 2020, 10, 510. [CrossRef]

169. Geoffrion, L.D.; Hesabizadeh, T.; Medina-Cruz, D.; Kusper, M.; Taylor, P.; Vernet-Crua, A.; Chen, J.; Ajo, A.; Webster, T.J.; Guisbiers, G. Naked Selenium Nanoparticles for Antibacterial and Anticancer Treatments. ACS Omega 2020, 5, $2660-2669$. [CrossRef]

170. Kang, S.-M.; Jang, S.-C.; Heo, N.S.; Oh, S.Y.; Cho, H.-J.; Rethinasabapathy, M.; Vilian, A.T.E.; Han, Y.-K.; Roh, C.; Huh, Y.S. Cesium-Induced Inhibition of Bacterial Growth of Pseudomonas Aeruginosa PAO1 and Their Possible Potential Applications for Bioremediation of Wastewater. J. Hazard. Mater. 2017, 338, 323-333. [CrossRef]

171. Lellouche, J.; Friedman, A.; Gedanken, A.; Banin, E. Antibacterial and Antibiofilm Properties of Yttrium Fluoride Nanoparticles. Int. J. Nanomed. 2012, 7, 5611-5624. [CrossRef]

172. Adams, C.P.; Walker, K.A.; Obare, S.O.; Docherty, K.M. Size-Dependent Antimicrobial Effects of Novel Palladium Nanoparticles. PLoS ONE 2014, 9, e85981. [CrossRef]

173. Mohana, S.; Sumathi, S. Multi-Functional Biological Effects of Palladium Nanoparticles Synthesized Using Agaricus Bisporus. J. Clust. Sci. 2020, 31, 391-400. [CrossRef]

174. Xu, C.; Akakuru, O.U.; Zheng, J.; Wu, A. Applications of Iron Oxide-Based Magnetic Nanoparticles in the Diagnosis and Treatment of Bacterial Infections. Front. Bioeng. Biotechnol. 2019, 7, 141. [CrossRef]

175. Kim, T.; Zhang, Q.; Li, J.; Zhang, L.; Jokerst, J.V. A Gold/Silver Hybrid Nanoparticle for Treatment and Photoacoustic Imaging of Bacterial Infection. ACS Nano 2018, 12, 5615-5625. [CrossRef]

176. Wu, W.; Mao, D.; Cai, X.; Duan, Y.; Hu, F.; Kong, D.; Liu, B. ONOO ${ }^{-}$and $\mathrm{ClO}^{-}$Responsive Organic Nanoparticles for Specific in Vivo Image-Guided Photodynamic Bacterial Ablation. Chem. Mater. 2018, 30, 3867-3873. [CrossRef]

177. Qin, H.; Cao, H.; Zhao, Y.; Zhu, C.; Cheng, T.; Wang, Q.; Peng, X.; Cheng, M.; Wang, J.; Jin, G.; et al. In Vitro and in Vivo Anti-Biofilm Effects of Silver Nanoparticles Immobilized on Titanium. Biomaterials 2014, 35, 9114-9125. [CrossRef]

178. Bai, X.; Li, L.; Liu, H.; Tan, L.; Liu, T.; Meng, X. Solvothermal Synthesis of ZnO Nanoparticles and Anti-Infection Application in Vivo. ACS Appl. Mater. Interfaces 2015, 7, 1308-1317. [CrossRef]

179. Xu, T.; Zhang, J.; Zhu, Y.; Zhao, W.; Pan, C.; Ma, H.; Zhang, L. A Poly(Hydroxyethyl Methacrylate)-Ag Nanoparticle Porous Hydrogel for Simultaneous in Vivo Prevention of the Foreign-Body Reaction and Bacterial Infection. Nanotechnology 2018, 29, 395101. [CrossRef] 
180. Wang, C.; Zhao, W.; Cao, B.; Wang, Z.; Zhou, Q.; Lu, S.; Lu, L.; Zhan, M.; Hu, X. Biofilm-Responsive Polymeric Nanoparticles with Self-Adaptive Deep Penetration for In Vivo Photothermal Treatment of Implant Infection. Chem. Mater. 2020, 32, 7725-7738. [CrossRef]

181. Cheng, H.; Li, Y.; Huo, K.; Gao, B.; Xiong, W. Long-Lasting in Vivo and in Vitro Antibacterial Ability of Nanostructured Titania Coating Incorporated with Silver Nanoparticles: Antibacterial Ability of Silver Nanoparticles. J. Biomed. Mater. Res. 2014, 102, 3488-3499. [CrossRef]

182. González, B.; Colilla, M.; Díez, J.; Pedraza, D.; Guembe, M.; Izquierdo-Barba, I.; Vallet-Regí, M. Mesoporous Silica Nanoparticles Decorated with Polycationic Dendrimers for Infection Treatment. Acta Biomater. 2018, 68, 261-271. [CrossRef]

183. Mas, N.; Galiana, I.; Mondragón, L.; Aznar, E.; Climent, E.; Cabedo, N.; Sancenón, F.; Murguía, J.R.; Martínez-Máñez, R.; Marcos, M.D.; et al. Enhanced Efficacy and Broadening of Antibacterial Action of Drugs via the Use of Capped Mesoporous Nanoparticles. Chem. Eur. J. 2013, 19, 11167-11171. [CrossRef]

184. Ruehle, B.; Clemens, D.L.; Lee, B.-Y.; Horwitz, M.A.; Zink, J.I. A Pathogen-Specific Cargo Delivery Platform Based on Mesoporous Silica Nanoparticles. J. Am. Chem. Soc. 2017, 139, 6663-6668. [CrossRef]

185. Xu, T.; Li, J.; Zhang, S.; Jin, Y.; Wang, R. Integration of Diagnosis and Treatment in the Detection and Kill of S.Aureus in the Whole Blood. Biosens. Bioelectron. 2019, 142, 111507. [CrossRef] [PubMed]

186. Kavruk, M.; Celikbicak, O.; Ozalp, V.C.; Borsa, B.A.; Hernandez, F.J.; Bayramoglu, G.; Salih, B.; Arica, M.Y. Antibiotic Loaded Nanocapsules Functionalized with Aptamer Gates for Targeted Destruction of Pathogens. Chem. Commun. 2015, 51, 8492-8495. [CrossRef] [PubMed]

187. Yang, S.; Han, X.; Yang, Y.; Qiao, H.; Yu, Z.; Liu, Y.; Wang, J.; Tang, T. Bacteria-Targeting Nanoparticles with MicroenvironmentResponsive Antibiotic Release to Eliminate Intracellular Staphylococcus Aureus and Associated Infection. ACS Appl. Mater. Interfaces 2018, 10, 14299-14311. [CrossRef]

188. Rathnayake, K.; Patel, U.; Pham, C.; McAlpin, A.; Budisalich, T.; Jayawardena, S.N. Targeted Delivery of Antibiotic Therapy to Inhibit Pseudomonas aeruginosa Using Lipid-Coated Mesoporous Silica Core-Shell Nanoassembly. ACS Appl. Bio Mater. 2020, 3, 6708-6721. [CrossRef]

189. Zhou, J.; Jayawardana, K.W.; Kong, N.; Ren, Y.; Hao, N.; Yan, M.; Ramström, O. Trehalose-Conjugated, Photofunctionalized Mesoporous Silica Nanoparticles for Efficient Delivery of Isoniazid into Mycobacteria. ACS Biomater. Sci. Eng. 2015, 1, 1250-1255. [CrossRef]

190. Mudakavi, R.J.; Vanamali, S.; Chakravortty, D.; Raichur, A.M. Development of Arginine Based Nanocarriers for Targeting and Treatment of Intracellular Salmonella. RSC Adv. 2017, 7, 7022-7032. [CrossRef]

191. Chen, X.; Liu, Y.; Lin, A.; Huang, N.; Long, L.; Gang, Y.; Liu, J. Folic Acid-Modified Mesoporous Silica Nanoparticles with PH-Responsiveness Loaded with Amp for an Enhanced Effect against Anti-Drug-Resistant Bacteria by Overcoming Efflux Pump Systems. Biomater. Sci. 2018, 6, 1923-1935. [CrossRef]

192. Qi, G.; Li, L.; Yu, F.; Wang, H. Vancomycin-Modified Mesoporous Silica Nanoparticles for Selective Recognition and Killing of Pathogenic Gram-Positive Bacteria Over Macrophage-Like Cells. ACS Appl. Mater. Interfaces 2013, 5, 10874-10881. [CrossRef]

193. Pedraza, D.; Díez, J.; Isabel-Izquierdo-Barba; Colilla, M.; Vallet-Regí, M. Amine-Functionalized Mesoporous Silica Nanoparticles: A New Nanoantibiotic for Bone Infection Treatment. Biomed. Glasses 2018, 4, 1-12. [CrossRef]

194. Martínez-Carmona, M.; Izquierdo-Barba, I.; Colilla, M.; Vallet-Regí, M. Concanavalin A-Targeted Mesoporous Silica Nanoparticles for Infection Treatment. Acta Biomater. 2019, 96, 547-556. [CrossRef]

195. LiPuma, J.J.; Rathinavelu, S.; Foster, B.K.; Keoleian, J.C.; Makidon, P.E.; Kalikin, L.M.; Baker, J.R. In Vitro Activities of a Novel Nanoemulsion against Burkholderia and Other Multidrug-Resistant Cystic Fibrosis-Associated Bacterial Species. Antimicrob. Agents Chemother. 2009, 53, 249-255. [CrossRef] [PubMed]

196. Hemmila, M.R.; Mattar, A.; Taddonio, M.A.; Arbabi, S.; Hamouda, T.; Ward, P.A.; Wang, S.C.; Baker, J.R. Topical Nanoemulsion Therapy Reduces Bacterial Wound Infection and Inflammation after Burn Injury. Surgery 2010, 148, 499-509. [CrossRef] [PubMed]

197. Hwang, Y.Y.; Ramalingam, K.; Bienek, D.R.; Lee, V.; You, T.; Alvarez, R. Antimicrobial Activity of Nanoemulsion in Combination with Cetylpyridinium Chloride in Multidrug-Resistant Acinetobacter Baumannii. Antimicrob. Agents Chemother. 2013, 57, 3568-3575. [CrossRef]

198. Ghaderi, L.; Moghimi, R.; Aliahmadi, A.; McClements, D.J.; Rafati, H. Development of Antimicrobial Nanoemulsion-Based Delivery Systems against Selected Pathogenic Bacteria Using a Thymol-Rich Thymus Daenensis Essential Oil. J. Appl. Microbiol. 2017, 123, 832-840. [CrossRef] [PubMed]

199. Krishnamoorthy, R.; Athinarayanan, J.; Periasamy, V.S.; Adisa, A.R.; Al-Shuniaber, M.A.; Gassem, M.A.; Alshatwi, A.A. Antimicrobial Activity of Nanoemulsion on Drug-Resistant Bacterial Pathogens. Microb. Pathog. 2018, 120, 85-96. [CrossRef]

200. Coune, A. Liposomes as Drug Delivery System in the Treatment of Infectious Diseases. Potential Applications and Clinical Experience. Infection 1988, 16, 141-147. [CrossRef]

201. Henry, B.D.; Neill, D.R.; Becker, K.A.; Gore, S.; Bricio-Moreno, L.; Ziobro, R.; Edwards, M.J.; Mühlemann, K.; Steinmann, J.; Kleuser, B.; et al. Engineered Liposomes Sequester Bacterial Exotoxins and Protect from Severe Invasive Infections in Mice. Nat. Biotechnol. 2015, 33, 81-88. [CrossRef]

202. Jiménez-Jiménez, C.; Manzano, M.; Vallet-Regí, M. Nanoparticles Coated with Cell Membranes for Biomedical Applications. Biology 2020, 9, 406. [CrossRef] 
203. Gao, F.; Xu, L.; Yang, B.; Fan, F.; Yang, L. Kill the Real with the Fake: Eliminate Intracellular Staphylococcus Aureus Using Nanoparticle Coated with Its Extracellular Vesicle Membrane as Active-Targeting Drug Carrier. ACS Infect. Dis. 2019, 5, $218-227$. [CrossRef]

204. Whitlow, C.B. Bacterial Sexually Transmitted Diseases. Clin. Colon Rectal. Surg. 2004, 17, 209-214. [CrossRef]

205. Li, L.-H.; Yen, M.-Y.; Ho, C.-C.; Wu, P.; Wang, C.-C.; Maurya, P.K.; Chen, P.-S.; Chen, W.; Hsieh, W.-Y.; Chen, H.-W. Non-Cytotoxic Nanomaterials Enhance Antimicrobial Activities of Cefmetazole against Multidrug-Resistant Neisseria Gonorrhoeae. PLoS ONE 2013, 8, e64794. [CrossRef]

206. Lucío, M.I.; Kyriazi, M.-E.; Hamilton, J.; Batista, D.; Sheppard, A.; Sams-Dodd, E.; Humbert, M.V.; Hussain, I.; Christodoulides, M.; Kanaras, A.G. Bactericidal Effect of 5-Mercapto-2-Nitrobenzoic Acid-Coated Silver Nanoclusters against Multidrug-Resistant Neisseria Gonorrhoeae. ACS Appl. Mater. Interfaces 2020, 12, 27994-28003. [CrossRef]

207. Alqahtani, F.; Aleanizy, F.; El Tahir, E.; Alhabib, H.; Alsaif, R.; Shazly, G.; AlQahtani, H.; Alsarra, I.; Mahdavi, J. Antibacterial Activity of Chitosan Nanoparticles Against Pathogenic N. Gonorrhoea. Int. J. Nanomed. 2020, 15, 7877-7887. [CrossRef]

208. Yang, S.; Traore, Y.; Jimenez, C.; Ho, E.A. Autophagy Induction and PDGFR- $\beta$ Knockdown by SiRNA-Encapsulated Nanoparticles Reduce Chlamydia Trachomatis Infection. Sci. Rep. 2019, 9, 1306. [CrossRef]

209. Costerton, J.W. Bacterial Biofilms: A Common Cause of Persistent Infections. Science 1999, 284, 1318-1322. [CrossRef]

210. Parsek, M.R.; Greenberg, E.P. Sociomicrobiology: The Connections between Quorum Sensing and Biofilms. Trends in Microbiology 2005, 13, 27-33. [CrossRef]

211. Deva, A.K.; Adams, W.P.; Vickery, K. The Role of Bacterial Biofilms in Device-Associated Infection. Plast. Reconstr. Surg. 2013, 132, 1319-1328. [CrossRef]

212. Lewis, K. Riddle of Biofilm Resistance. Antimicrob. Agents Chemother. 2001, 45, 999-1007. [CrossRef]

213. Jamal, M.; Ahmad, W.; Andleeb, S.; Jalil, F.; Imran, M.; Nawaz, M.A.; Hussain, T.; Ali, M.; Rafiq, M.; Kamil, M.A. Bacterial Biofilm and Associated Infections. J. Chin. Med Assoc. 2018, 81, 7-11. [CrossRef]

214. Lebeaux, D.; Ghigo, J.-M.; Beloin, C. Biofilm-Related Infections: Bridging the Gap between Clinical Management and Fundamental Aspects of Recalcitrance toward Antibiotics. Microbiol. Mol. Biol. Rev. 2014, 78, 510-543. [CrossRef]

215. Colilla, M.; Vallet-Regí, M. Targeted Stimuli-Responsive Mesoporous Silica Nanoparticles for Bacterial Infection Treatment. Int. J. Mol. Sci. 2020, 21, 8605. [CrossRef] [PubMed]

216. Vallet-Regí, M.; Lozano, D.; González, B.; Izquierdo-Barba, I. Biomaterials against Bone Infection. Adv. Healthcare Mater. 2020, 9 , 2000310. [CrossRef]

217. Castillo, R.R.; Lozano, D.; Vallet-Regí, M. Mesoporous Silica Nanoparticles as Carriers for Therapeutic Biomolecules. Pharmaceutics 2020, 12, 432. [CrossRef] [PubMed]

218. Villegas, M.F.; Garcia-Uriostegui, L.; Rodríguez, O.; Izquierdo-Barba, I.; Salinas, A.J.; Toriz, G.; Vallet-Regí, M.; Delgado, E. Lysine-Grafted MCM-41 Silica as an Antibacterial Biomaterial. Bioengineering 2017, 4, 80. [CrossRef]

219. Zhao, Y.; Sun, X.; Zhang, G.; Trewyn, B.G.; Slowing, I.I.; Lin, V.S.-Y. Interaction of Mesoporous Silica Nanoparticles with Human Red Blood Cell Membranes: Size and Surface Effects. ACS Nano 2011, 5, 1366-1375. [CrossRef] 